\title{
General geology, alteration, and iron deposits in the Palaeo- proterozoic Misi region, northern Finland
}

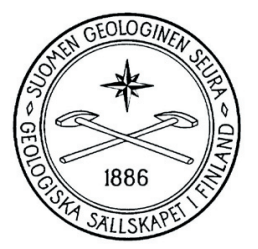

\author{
Tero Nitranen ${ }^{\mathrm{I}) *}$, Eero Hanski ${ }^{2)}$ and Pasi Eilu ${ }^{3)}$ \\ 1) Department of Geology, P.O. Box 64, FIN-00014 University of Helsinki, Finland \\ ${ }^{2)}$ Geological Survey of Finland, P.O. Box 77, FIN-96101 Rovaniemi, Finland \\ ${ }^{3)}$ Geological Survey of Finland, P.O. Box 96, FIN-02151 Espoo, Finland
}

\begin{abstract}
The Paleoproterozoic Misi region forms the northeastern part of the Peräpohja Schist Belt in northern Finland. The area comprises mafic volcanic and sedimentary rocks, differentiated gabbros, and late-orogenic granitoids.

Three geochemically different mafic volcanic units were recognised: LREE-depleted amygdaloidal lavas, slightly LREE-enriched lavas, and mafic tuffs that have a flat REE pattern. Sedimentary rocks include arkosites, mica gneisses, dolomitic marbles, quartzites, tuffites, mica schists, calc-silicate rocks and graphite-bearing schists. Two types of gabbros were identified: one with a LREE-enriched pattern and another with flat REE pattern. The age of the former is according to Perttunen and Vaasjoki (200 I) 21 I7 44 Ma, whereas there is no age determination for the latter. The granitoid intrusions belong to the ca. I $800 \mathrm{Ma}$ late-orogenic group of the Central Lapland Granitoid Complex.The geochemistry and the stable isotope data on mafic lavas and dolomitic marbles show similarities with the mafic volcanic rocks and marbles of the lower part of the Kivalo group in the western part of Peräpohja Schist Belt.

Peak metamorphic conditions in the region vary from upper-greenschist to upper-amphibolite facies. Three major stages of deformation were distinguished: N-S compressional $D_{1}$ with ductile deformation, NE-SW compressional $D_{2}$ with ductile to brittle-ductile deformation, and $\mathrm{E}-\mathrm{W}$ compressional $\mathrm{D}_{3}$ with brittle deformation.

Several magnetite occurrences are known in the region and four of those have been mined for iron. The ores are mainly composed of magnetite with minor haematite, pyrite, chalcopyrite and bornite. Besides iron, the ores contain small amounts of P, $S$ and $V$ as well as trace amounts of $\mathrm{Cu}, \mathrm{Co}$, Te and $\mathrm{Au}$. The magnetite bodies are hosted by skarnoids within the ca. 2220-2/20 Ma dolomitic marble-quartzite sequence, and highly differentiated, intensely albitised, LREE-enriched gabbro.

Multistage and -type alteration is characteristic for the entire region. The styles of alteration in the region are: scapolitisation, regional and local albitisation, sericitisation and silicification associated with a major shear zone, and late carbonatisation and carbonate veining associated with brecciation of the ores and their wall rocks.

Local intense albitisation and formation of skarnoids and magnetite ores took place during the pre- $\mathrm{D}$, or $\mathrm{D}$, faulting or shearing which postdate the intrusion of $2120 \mathrm{Ma}$ gabbros. The iron was mobilized from the mafic to intermediate country rocks and/or marble sequence which possibly contained sedimentary iron formation. Regional alteration with the local intense albitisation and ore formation show similar features to the iron oxide-copper-gold type deposits, although the known deposits in the Misi region only contain trace amounts of gold and copper.
\end{abstract}

Key words: metavolcanic rocks, metasedimentary rocks, gabbros, skarn, iron ores, geochemistry, alteration, Paleoproterozoic, Misi, Lapland Province, Finland

\footnotetext{
* Corresponding author

e-mail: tero.niiranen@helsinki.fi
} 


\section{Introduction}

The Palaeoproterozoic Misi region is located in northern Finland (Fig. 1) where it forms the northeastern corner of the Peräpohja Schist Belt, immediately to the south of the Central Lapland Granitoid Complex. In 1921, local villagers detected magnetic anomalies in the Kärväsvaara area, in the NE-part of the Misi area. This quickly led to exploration activities and, eventually in 1937, to the discovery of a small magnetite deposit at Kärväsvaara (Otanmäki Oy, unpubl. exploration report, 1937). The area was under continuous exploration and mining for iron ore until the closure of the Raajärvi mine in 1975. Several small magnetite deposits were found during this period, four of which were mined by Otanmäki Oy (Fig. 1): Kärväsvaara 1958-1967, Leveäselkä 1972-1974, and Raajärvi and Puro 1961-1975 (Westerlund, 1965; Westerlund et al., 1968; Siirama, 1976; Lindholm, 1976). The total ore production of the area exceeded 7 million tons (Table 1).

A few papers have been published on the geology and mineralogy of the magnetite deposits and their country rocks. An unpublished exploration report by Otanmäki Oy in 1937 describes exploration, discovery, geology and mineralogy of the Kärväsvaara mine and the small magnetite deposits near Kärväsvaara. Marmo (1952), Runolinna (1959), Westerlund (1965), Westerlund et al. (1968), Lindholm (1976) and Siirama (1976) have described the Kärväsvaara, Raajärvi and Leveäselkä mine in detail. Saastamoinen (1965) studied the mineralogy of the country rocks and ore of Kärväsvaara and Raajärvi. In the sole major paper from the area, Nuu-

Table I. Ores mined during 1958-1975 (Nuutilainen, 1968; Lindholm, 1976; Siirama, 1976).

\begin{tabular}{lcccc}
\hline Deposit & Resources & $\begin{array}{c}\text { Total ore } \\
\text { production }\end{array}$ & $\begin{array}{c}\text { Average } \\
\text { Fe wt.\% }\end{array}$ & $\begin{array}{c}\text { Average } \\
\text { S wt.\% }\end{array}$ \\
\hline Kärväsvaara & $1.35 \mathrm{Mt}$ & $1.10 \mathrm{Mt}$ & 53 & 1.04 \\
Raajärvi & $6.55 \mathrm{Mt}$ & $5.66 \mathrm{Mt}$ & 47 & 0.11 \\
Puro & $0.60 \mathrm{Mt}$ & $0.06 \mathrm{Mt}$ & 53 & 0.3 \\
Leveäselkä & $1.20 \mathrm{Mt}$ & $0.30 \mathrm{Mt}$ & 46 & 0.1 \\
\hline
\end{tabular}

tilainen (1968) describes the geology of the Misi region and proposed a magmatic model for the iron ore formation.

The aim of this study is to present updated data on the general geology of the Misi region, describe characteristics of the alteration phenomena encountered in the area, summarise salient features of the iron deposits, and suggest a model for their origin.

The research methods employed in our investigations include bedrock mapping, detailed logging of about $4500 \mathrm{~m}$ of drill core mainly from the Raajärvi and Puro deposits, and microscopic investigation of 280 polished thin sections. Approximately 250 rock samples were collected from outcrops and 300 samples from the drill core. Since all quarries and mines are now filled with water and no outcrops occur in their proximity, the macroscopic study of the deposits is essentially based on drill core material. Some data were also acquired from the waste rock piles.

Semiquantitative mineral analyses were made using SEM-EDS at Geological Survey of Finland (GTK). Serpentine and carbonate minerals were identified by XRD at the Department of Geology, University of Helsinki. In total, 55 samples were analysed by XRF on pressed powder pellets for major elements and $\mathrm{As}, \mathrm{Ba}, \mathrm{Bi}$, $\mathrm{Ce}, \mathrm{Cl}, \mathrm{Cr}, \mathrm{Cu}, \mathrm{Ga}, \mathrm{La}, \mathrm{Mo}, \mathrm{Nb}, \mathrm{Ni}, \mathrm{Pb}, \mathrm{Rb}$, $\mathrm{Sb}, \mathrm{Sc}, \mathrm{Sn}, \mathrm{Sr}, \mathrm{Th}, \mathrm{U}, \mathrm{V}, \mathrm{Y}, \mathrm{Zn}, \mathrm{Zr}$. In addition, $\mathrm{S}$ and $\mathrm{C}$ were analysed with $\mathrm{C} / \mathrm{S}$-analyser (Leco). Of these samples, 22 were also analysed by ICP-MS for REE, Co, Hf, Nb, Sc, Ta, Th, U, V, Y, Yb, and Zr. Also, 64 samples from the iron ore were analysed by ICP-AES for Ag, As, Ba, Be, Ca, Co, Cr, Cu, Fe, K, La, Li, Ni, P, $\mathrm{Pb}, \mathrm{S}, \mathrm{Sb}, \mathrm{Sr}, \mathrm{Th}, \mathrm{Ti}, \mathrm{V}, \mathrm{Zn}$ and by GFAAS for $\mathrm{Au}, \mathrm{Bi}, \mathrm{Sb}$ and $\mathrm{Te}$. All analyses were performed at the GTK. Also, 24 samples of gabbro and albitised rocks that do not show any oriented fabric were measured for anisotropy of magnetic susceptibility (AMS) by using the KLY-2 KappaBridge equipment in the Palaeomagnetic laboratory of the GTK.

Because all supracrustal rocks in the belt are metamorphosed, the prefix "meta" is implied 


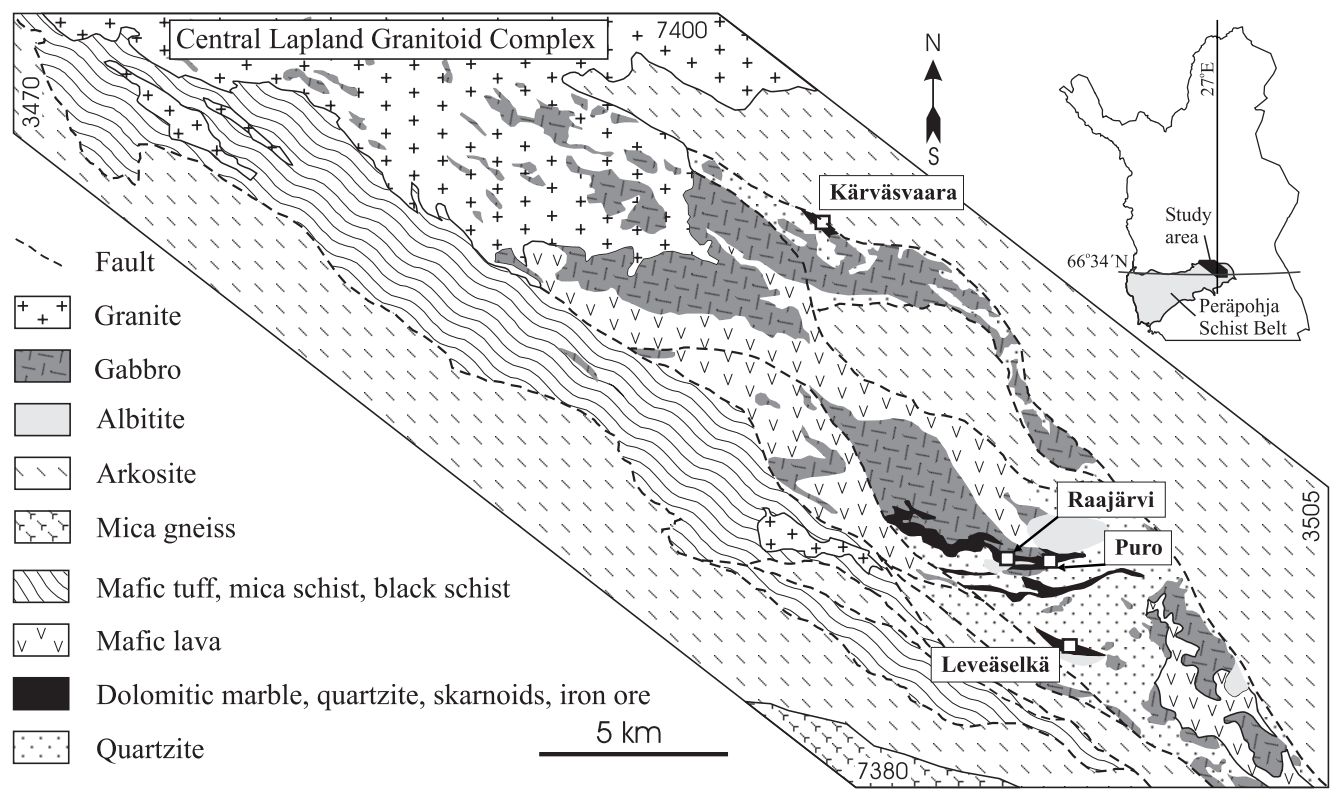

Fig. I. Location and general geological features of the Misi region. Coordinate system: Finnish national (KKJ).

but omitted from the rock names in this work. We use the term skarn in a broad sense without any petrogenetic connotation. As skarnoids, we refer to rocks chiefly consisting of serpentine, tremolite-actinolite, chlorite or talc. "Albitite" is used here for the rocks which are albitised in such a degree that there is no textural indication for a protolith.

\section{Regional geological setting}

The Misi region is NW trending, about $50 \mathrm{~km}$ long and $12 \mathrm{~km}$ wide area forming the easternmost corner of the Peräpohja schist belt. It is composed of Palaeoproterozoic volcanic units, sedimentary rocks, and numerous gabbroic intrusives (Fig. 1). It is bounded, probably with tectonic contacts, by arkosites and arkosic gneisses both to the southwest and northeast. Similar arkosic rocks are also found as tectonic wedges within the Misi sediments. Mafic volcanic rocks with amygdaloidal structure dominate the central part of the belt, while quartzitic and less abundant carbonate rocks and various alteration products of the latter are found in the south-eastern part of the belt and in its northeastern margin. The iron deposits are associated with the marbles and quartzites. The southwestern margin of the area is occupied by mafic tuffs and tuffites and intervening pelitic sedimentary rocks including graphitic schist.

The gabbros have intruded into quartzites, marbles and amygdaloidal lavas, which are regarded as the oldest lithological unit in the area. On the other hand, the gabbros rarely occur within the mafic tuffite and pelitic schist sequences, and have never been discovered within the arkosites. From the north, granitic magmas of the Central Lapland Granitoid Complex have intruded into the Misi region, and there is a granite-dominated area adjacent to the study area that contains large inclusions of gabbro and supracrustal rocks. Some granitic bodies occur within the supracrustal belt, the largest of which is the ca. 3-km-long granite to the west of the Raajärvi mine (Fig. 1). In addition, numerous pegmatite dykes are present all around the belt, varying in thickness from less than one meter to ten meters. Locally, highly altered, albiterich rocks occur next to gabbroic and sedimen- 
tary rocks. The most notable of these altered domains is marked as albitite immediately to the east of the Raajärvi mine in Figure 1.

Regional metamorphic grade is lowest in the central part and highest on the flanks of the study area. On the SW flank, the metamorphic grade is at upper-amphibolite facies, and is only slightly lower on the NE flank. In the central part of the belt, mineral assemblages indicate peak-metamorphic conditions of upper-greenschist to lower-amphibolite facies.

Three deformation stages have been identified in the area: 1) the oldest one is related to a N-S compression $\left(\mathrm{D}_{1}\right)$ with ductile deformation and isoclinal folding, 2) the second one is related to SW-NE compression $\left(\mathrm{D}_{2}\right)$ with ductile folding, and 3) the youngest one is related to E-W compression $\left(\mathrm{D}_{3}\right)$, brittle to brittleductile deformation, and intrusion of pegmatite and felsic dykes. The $\mathrm{D}_{3}$ stage is also recorded as magnetic anisotropy in gabbros, arkosites, albitised arkosites and albitites, as indicated by the AMS investigation during this study. The relationship between deformation, intrusions and alteration are presented in more detail in the discussion.

Perttunen and Vaasjoki (2001) have reported an U-Pb zircon age of $2117 \pm 4 \mathrm{Ma}$ for a gabbro from the Misi region. Granite and pegmatite dykes in the northern part of the area represent the youngest rocks in the region, and have been observed to crosscut albitised volcanic rocks and gabbros. These granites belong to the ca. 1800 Ma granitoids of the Central Lapland Granitoid Complex (Hanski et al., 2001). Lauerma (1982) has published a U-Pb zircon age of $1770 \pm 8 \mathrm{Ma}$ for a porphyritic granite sampled near the northern margin of the Peräpohja Schist Belt, ca. $50 \mathrm{~km}$ west of the Misi region.

\section{Rock types and their geochemical characteristics}

\section{I. Mafic volcanic rocks}

Three different types of mafic volcanic rocks were identified in the Misi region with two of them being mafic lavas and one a mafic tuff. The lavas are described below and the tuffs in the following subsection.

By volume, most of the mafic volcanic rocks in the Misi region belong to a tholeiitic group characterised by thick lava flows with an amygdaloidal texture. This group, designated as the Type 1, dominate the central parts, but has also been found elsewhere in the area (Fig. 1). Their dominant texture is granoblastic, locally foliated. Green hornblende and variably sericitised plagioclase are the major minerals, and magnetite a typical accessory component. The rocks range from fine- to medium-grained depending on the position of the sample in a flow.

Type 2 lavas commonly are intensely albitised but still show their primary hyaloclastic and breccia structures. These rocks occur in the northeastern end of the central volcanic zone. They are granoblastic, fine- to medium-grained, and chiefly comprise green hornblende, sericitised and saussuritised plagioclase, and diopside. Minor minerals include magnetite and titanite.

Chemical composition of the mafic lavas are shown in Table 2 and plotted in Figures 2 and 3. In the classification scheme of Winchester and Floyd (1977), both Type 1 and 2 lavas straddle on the border between sub-alkalic basalt and basalt/andesite with some scatter to the sub-alkalic basalt field (Fig. 2a). On the Jensen cation plot (Fig. 2b), the lavas have some overlap and fall in the field of Fe-tholeiites, except for two samples of Type 2 which plot in the basaltic komatiite field. As shown in Figures 2ce, the two lava types can be distinguished in the chondrite-normalised REE diagrams and primitive mantle-normalised spidergrams. Type 1 shows a slightly depleted and Type 2 a slightly enriched trend for LREE. The spidergram for Type 1 (Fig. 2d) shows that these rocks are only slightly enriched in incompatible elements in relation to primitive mantle. Only $\mathrm{Rb}$ and $\mathrm{K}$ show a significant enrichment but the large scatter suggests that this is a secondary feature probably related to alteration. The behaviour of incompatible elements for Type 2 (Fig. 2e) is similar to that for Type 1 with the exception of a 
Table 2. Representative major rock type analyses of the Misi region. I:Type I mafic lava, 2: Type 2 mafic lava, 3: LREE-enriched gabbro, 4: Flat-REE gabbro, 5: Granite, 6: Mafic tuff, 7: Arkosite, 8: Graphite bearing schist. XRF data unless otherwise mentioned.

\begin{tabular}{|c|c|c|c|c|c|c|c|c|}
\hline & 1. & 2. & 3. & 4. & 5. & 6. & 7. & 8. \\
\hline $\mathrm{SiO}_{2}$ wt. $\%$ & 49.93 & 47.36 & 49.97 & 49.20 & 74.80 & 48.04 & 75.85 & 64.74 \\
\hline $\mathrm{TiO}_{2}^{2}$ & 0.98 & 1.29 & 0.87 & 1.07 & 0.13 & 0.99 & 0.14 & 0.57 \\
\hline $\mathrm{AlO}^{2}$ & 15.03 & 12.58 & 15.53 & 14.00 & 13.69 & 14.08 & 13.27 & 7.14 \\
\hline $\mathrm{Fe}_{2}^{2} \mathrm{O}_{3}^{3}$ tot & 12.25 & 15.29 & 8.48 & 14.20 & 1.18 & 13.44 & 0.82 & 14.00 \\
\hline $\mathrm{MnO}^{2}$ & 0.27 & 0.24 & 0.10 & 0.20 & 0.01 & 0.22 & 0.01 & 1.08 \\
\hline $\mathrm{MgO}$ & 6.76 & 6.65 & 6.35 & 6.02 & 0.21 & 7.45 & 0.22 & 3.40 \\
\hline $\mathrm{CaO}$ & 8.51 & 8.57 & 9.23 & 10.60 & 0.66 & 8.94 & 0.66 & 4.48 \\
\hline $\mathrm{Na}_{2} \mathrm{O}$ & 3.91 & 3.67 & 4.39 & 2.20 & 3.88 & 4.18 & 4.15 & 0.68 \\
\hline $\mathrm{K} \mathrm{O}$ & 0.40 & 0.53 & 0.86 & 0.28 & 5.04 & 0.35 & 4.54 & 0.46 \\
\hline $\mathrm{P}_{2}^{2} \mathrm{O}_{5}$ & 0.06 & 0.10 & 0.11 & 0.08 & 0.04 & 0.07 & 0.09 & 0.33 \\
\hline Total & 98.09 & 96.27 & 95.90 & 97.85 & 99.65 & 97.76 & 99.75 & 96.88 \\
\hline Ba ppm & 47 & 64 & 143 & 80 & 407 & $<20$ & 276 & 145 \\
\hline $\mathrm{C}^{\mathrm{a}}$ & 200 & n.a. & 1900 & 100 & n.a. & 200 & n.a. & 12700 \\
\hline $\mathrm{Cl}$ & 865 & $<100$ & 9344 & 4100 & $<100$ & 719 & $<100$ & 3316 \\
\hline $\mathrm{Cr}$ & 265 & 42 & 96 & 80 & 4 & 134 & 4 & 82 \\
\hline $\mathrm{Cu}$ & 146 & 65 & 16 & 94 & $<20$ & 160 & $<20$ & 55 \\
\hline $\mathrm{Ga}$ & 17 & 16 & 17 & 23 & 21 & 16 & 20 & 15 \\
\hline $\mathrm{Ni}$ & 97 & 46 & 83 & 87 & $<20$ & 102 & $<20$ & 37 \\
\hline $\mathrm{Pb}$ & $<30$ & $<30$ & $<30$ & $<30$ & $<30$ & $<30$ & $<30$ & $<30$ \\
\hline $\mathrm{Rb}$ & 15 & 16 & 22 & $<10$ & 256 & $<10$ & 212 & 15 \\
\hline $\mathrm{S}^{\mathrm{a}}$ & $<100$ & n.a. & 900 & 200 & n.a. & 100 & n.a. & 12300 \\
\hline Sc & 42 & 43 & $<30$ & 45 & $<30$ & 45 & $<30$ & $<30$ \\
\hline $\mathrm{Sr}$ & 80 & 103 & 220 & 121 & 68 & 253 & 42 & 27 \\
\hline $\mathrm{V}$ & 270 & 303 & 179 & 275 & $<30$ & 286 & $<30$ & 69 \\
\hline Y & 19 & 24 & 13 & 23 & 23 & 23 & 18 & 22 \\
\hline $\mathrm{Zn}$ & 112 & 147 & 28 & 84 & $<20$ & 71 & $<20$ & 1554 \\
\hline $\mathrm{Zr}$ & 52 & 74 & 98 & 51 & 104 & 43 & 86 & 120 \\
\hline $\mathrm{Nb}^{b}$ & 1.60 & 4.01 & 4.33 & 2.18 & 12.3 & 2.18 & n.a. & n.a. \\
\hline $\mathrm{U}^{\mathrm{b}}$ & $<0.2$ & $<0.2$ & 0.76 & $<0.2$ & 5.59 & $<0.2$ & n.a. & n.a. \\
\hline $\mathrm{Th}^{\mathrm{b}}$ & $<0.5$ & 0.72 & 3.21 & $<0.5$ & 24.3 & $<0.5$ & n.a. & n.a. \\
\hline $\mathrm{La}^{\mathrm{b}}$ & 1.84 & 5.11 & 13.2 & 3.34 & 29.5 & 3.08 & n.a. & n.a. \\
\hline $\mathrm{Ce}^{\mathrm{b}}$ & 4.90 & 13.8 & 26.5 & 8.72 & 59.2 & 8.47 & n.a. & n.a. \\
\hline $\operatorname{Pr}^{\mathrm{b}}$ & 0.77 & 2.06 & 2.89 & 1.37 & 5.76 & 1.34 & n.a. & n.a. \\
\hline $\mathrm{Nd}^{\mathrm{b}}$ & 4.52 & 9.98 & 12.5 & 6.91 & 20.0 & 7.49 & n.a. & n.a. \\
\hline $\mathrm{Sm}^{\mathrm{b}}$ & 1.62 & 2.82 & 2.54 & 2.07 & 3.59 & 2.23 & n.a. & n.a. \\
\hline $\mathrm{Eu}^{\mathrm{b}}$ & 0.63 & 0.97 & 0.75 & 0.85 & 0.49 & 0.83 & n.a. & n.a. \\
\hline $\mathrm{Gd}^{\mathrm{b}}$ & 2.77 & 3.77 & 2.95 & 3.56 & 3.42 & 3.27 & n.a. & n.a. \\
\hline $\mathrm{Tb}^{\mathrm{b}}$ & 0.48 & 0.63 & 0.35 & 0.55 & 0.50 & 0.53 & n.a. & n.a. \\
\hline $\mathrm{Dy}^{\mathrm{b}}$ & 3.64 & 4.01 & 2.43 & 3.75 & 2.67 & 3.58 & n.a. & n.a. \\
\hline $\mathrm{Ho}^{b}$ & 0.79 & 0.86 & 0.43 & 0.85 & 0.54 & 0.72 & n.a. & n.a. \\
\hline $\mathrm{Er}^{\mathrm{b}}$ & 2.18 & 2.59 & 1.10 & 2.21 & 1.72 & 2.35 & n.a. & n.a. \\
\hline $\mathrm{Tm}^{\mathrm{b}}$ & 0.34 & 0.34 & 0.18 & 0.33 & 0.26 & 0.33 & n.a. & n.a. \\
\hline $\mathrm{Yb}^{\mathrm{b}}$ & 2.18 & 2.46 & 12.9 & 2.34 & 1.86 & 2.23 & n.a. & n.a. \\
\hline $\mathrm{Lu}^{\mathrm{b}}$ & 0.31 & 0.37 & 0.15 & 0.36 & 0.29 & 0.32 & n.a. & n.a. \\
\hline
\end{tabular}

n.a. $=$ not analysed

${ }^{a} \mathrm{LECO}$ analyses

${ }^{b} \mathrm{ICP}-\mathrm{MS}$ analyses

higher scatter of $\mathrm{K}, \mathrm{Rb}$ and $\mathrm{Sr}$. The distribution of the major elements and $\mathrm{Ni}, \mathrm{Cr}$ and $\mathrm{Zr}$ (Fig. 3) shows a weak scatter for Type 1 and a large scatter for Type 2. The behaviour of $\mathrm{Mg}, \mathrm{Ni}$ and $\mathrm{Cr}$ for Type 2 lavas suggests effects of fractional crystallisation as there is a good positive correlation between these elements. Fractionation of plagioclase could explain the negative $\mathrm{Eu}$ and $\mathrm{Sr}$ anomalies shown by Figures 2c and 2e. 

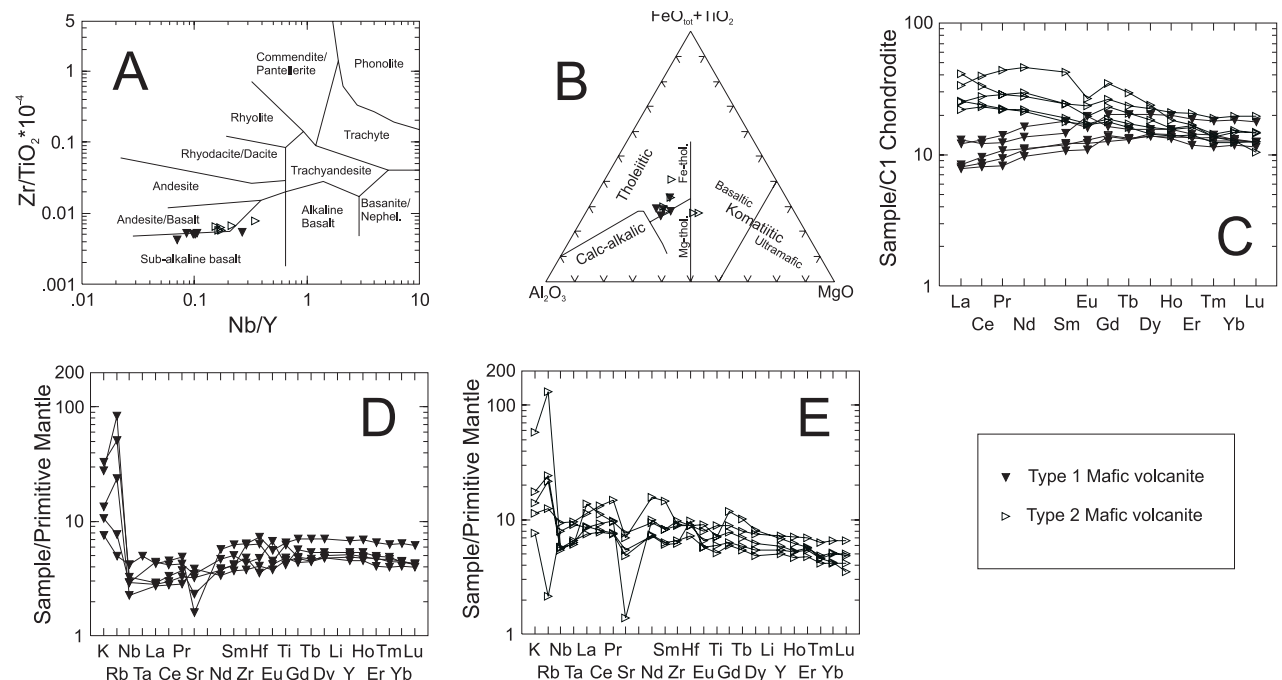

- Type 1 Mafic volcanite

$\triangleright$ Type 2 Mafic volcanite

Fig. 2. Mafic volcanic rocks on classification diagrams of a) Winchester \& Floyd (1977) and b) Jensen (1976), c) Chondrite-normalised lanthanide distribution of mafic volcanic rocks. Primitive mantle-normalised distribution of incompatible elements for d) Type I and e) Type 2 mafic lava. Normalising values from Sun \& McDonough ( 1989).
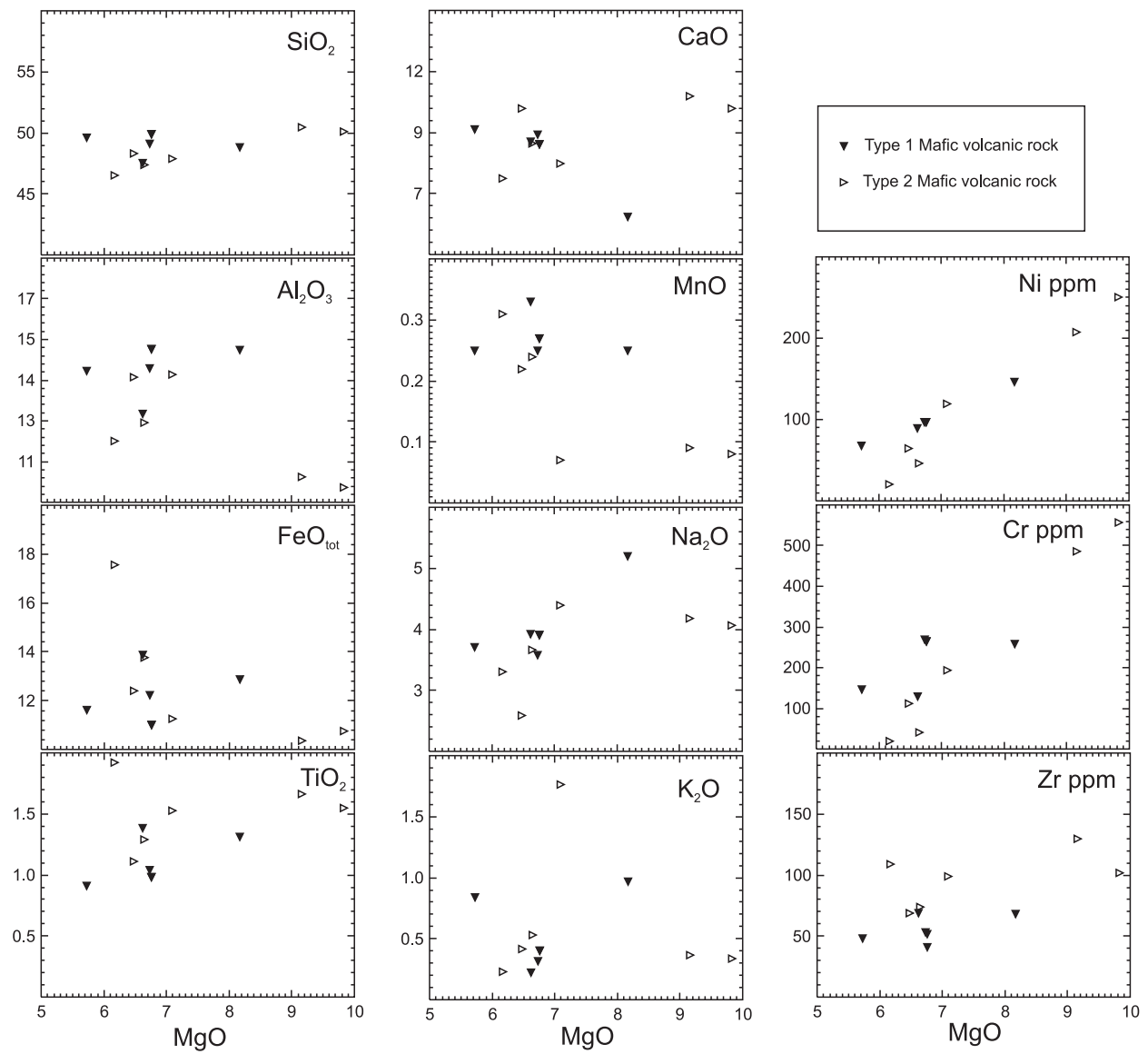

Fig. 3. Bivariant plots of the mafic lavas. Major elements are given in weight percent, minor elements in ppm. 

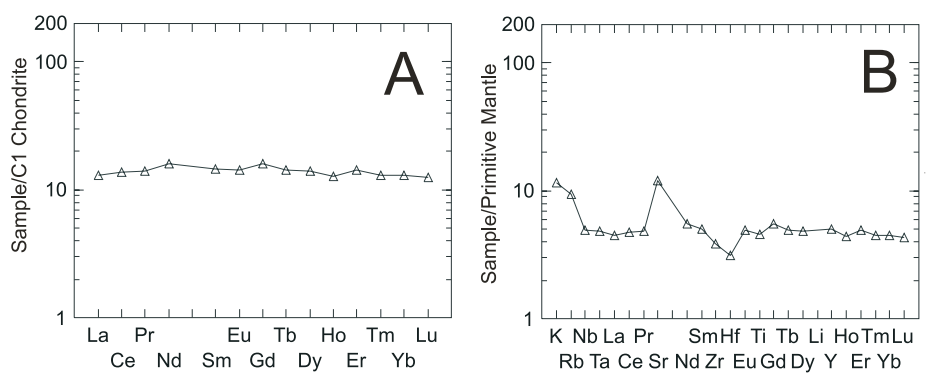

Fig. 4. a) Chondrite-normalised lanthanide distribution, and b) primitive mantle-normalised incompatible element distribution for mafic tuff. Normalising values from Sun \& McDonough (1989).

\subsection{Mafic volcaniclastic and associated meta- sedimentary rocks}

A NW-trending sequence of narrow units of mafic tuff and tuffite with graphite-bearing schist and calc-silicate interbeds is present in the southwestern margin of the Misi region (Fig. 1). These units are poorly exposed, but can be followed on aeromagnetic maps due to their high magnetic intensity. The rocks are moderately altered, mainly scapolitised and albitised. The calc-silicate- and graphite-bearing schist interbeds suggest a shallow-water depositional environment.

The tuffs are fine-grained (grain size 0.1$0.5 \mathrm{~mm}$ in diameter), layered, intensely foliated, dark-green rocks. Their major minerals are green hornblende, fine-grained plagioclase, finegrained magnetite and porphyroblasts of brown hornblende. Accessory minerals are titanite, biotite, pyrite and chalcopyrite.

Scapolite, epidote, albitic plagioclase and magnetite have been observed as alteration products in the tuffs. Scapolite forms rounded porphyroblasts, $<6 \mathrm{~mm}$ in diameter, and thin veins. Epidote forms thin veins and small patches and albite $<3 \mathrm{~cm}$ wide bands together with magnetite. Chemical composition of a mafic tuff is shown in Table 2 and Figures $4 \mathrm{a}$ and $4 \mathrm{~b}$. The tuffs have a geochemical affinity to Fe-tholeiite and display flat REE patterns (Fig. 4a).

The calc-silicate interbeds in the tuff-schist sequence consist of quartz, carbonate, magnetite, diopside, epidote, porphyroblasts of andraditic garnet and large, helisitic porphyroblasts of meionitic scapolite. The texture is granoblastic with a grain size of $0.4-1.2 \mathrm{~mm}$. Occasionally, the calc-silicate interbeds are completely metamorphosed to a diopside rock with only minor volumes of albite.

The graphite-bearing schist interbeds are granoblastic, and consist of quartz, brown biotite, green hornblende, garnet porphyroblasts and fine-grained graphite (for chemical composition, see Table 2). Accessory minerals include pyrrhotite and chalcopyrite.

\subsection{Quartzites and dolomitic marbles}

Quartzites are only exposed in a few outcrops NE of the Puro deposit (Fig. 1), but drilling and mining operations have shown that they occur as wall rocks of all magnetite deposits in the Misi region. The quartzites are completely recrystallised, but the primary layering and cross-bedding are commonly visible in outcrop. In lower parts of the quartzite sequence, there are intensely altered interlayers of tuffite, which comprise hornblende, albite, biotite, scapolite and accessory apatite, titanite, and magnetite.

Dolomitic marbles are present in the Raajärvi mine and, in smaller amounts, in the Kärväsvaara and Mustalampi deposits. The marbles are consistently associated with quartzites and contain quartzite interlayers. Mica-rich layers, which indicate the primary bedding, are commonly visible. Unaltered marble is mediumgrained $(0.2-0.6 \mathrm{~mm})$ and its texture granoblastic. Its molar $\mathrm{Ca} / \mathrm{Mg}$ ratio is very close to 1 indicating that the rock is rather pure dolomite (cf. Table 3). Muscovite and chlorite occur as impurities in the marble. Calcite is common only in 
the altered marbles: for example, it is abundant near the contact between the magnetite ore and the marble at Raajärvi.

Karhu (1993) reported a $\delta^{13} \mathrm{C}$ value of +12.6 $\pm 0.6 \%$ o (PDB) for the dolomitic marble from the Misi region. This is consistent with the high values measured for dolomites from dolomite formations of the Kivalo Group (Perttunen et al. 1995, Karhu 1993). These values represent the major positive $\delta^{13} \mathrm{C}$ anomaly observed in the 2220-2060 Ma carbonate sediments worldwide (Karhu \& Holland, 1996) implying extensive burial of organic carbon. The $\delta^{16} \mathrm{O}$ values for the dolomites in the Misi region vary from +19.2 to $+21.2 \%$ (SMOW), also being similar to the range of carbonate rocks in the western part of the Peräpohja Schist Belt (Karhu, 1993).

\subsection{Arkosites}

Arkosites form the southwestern and northeastern flanks of the Misi region (Fig. 1). In the SW flank, the high metamorphic grade (upperamphibolite facies), with recrystallisation and migmatitisation, has destroyed some of the primary structures and all primary textures. Even granitic leucosomes representing partial melting of the arkosite occur in the SW. In the NE flank, the original sedimentary structures, typically layering, can be seen. The arkositic sequences of the Misi region are thick; they can be followed for hundreds of meters across bedding. In the NE flank, also interbeds of amphibolite have been detected.

The arkosites are composed of quartz, plagioclase, muscovite, biotite, minor magnetite and, occasionally, cordierite porphyroblasts. Locally, the arkosites are rich in K-feldspar. Their texture is granoblastic and grain size $0.4-1.4 \mathrm{~mm}$ with coarser-grained varieties being characteristic in higher metamorphic grades. A chemical composition for the arkosite is presented in Table 2.

\subsection{Gabbros}

Based on mineral assemblages, the gabbroic intrusions of the Misi region can be divided into hornblende and pyroxene gabbros. The mineralogical differences reflect the degree of metamorphic alteration and are not directly related to geochemical differences which also suggest the presence of two different gabbros in the region.

The pyroxene gabbro typically has a subophitic to ophitic texture and a grain size of 1$5 \mathrm{~mm}$. It is composed of coarse-grained orthoand clinopyroxene, green hornblende, zoned plagioclase and small amounts of biotite, magnetite, titanite, zircon, pyrite, and chalcopyrite. A low degree of alteration is typical: plagioclase is partially replaced by scapolite and epidote, and pyroxenes by green hornblende and magnetite.

The hornblende gabbro is medium-grained (0.4-1.5 mm), hypidiomorphic, and normally unoriented. Locally, a subophitic texture is visible. Major minerals are zoned plagioclase and green hornblende. Biotite, titanite, magnetite, apatite, pyrite, chalcopyrite, zircon and, occasionally, relic pyroxenes occur in minor amounts. Epidote and scapolite occur as alteration products in a similar way as in the pyroxene gabbros.

Chemical composition of the Misi region gabbros are shown in Figures 5 and 6 and in Table 2. The bivariant major element plots for the gabbros (Fig. 5) show an extensive variation for almost all the elements depicted. The chondrite-normalised REE diagram for one gabbro type shows enrichment in LREE and, also, some variation in the concentration levels for all REE (Fig. 6a). Two gabbro samples show a totally different, flat, REE pattern and much less variation in the spidergrams than the LREEenriched gabbro (Figs. 6b-6d). However, for the major elements, the flat-REE gabbro differs significantly from the LREE-enriched gabbros only in their Fe, $\mathrm{K}$ and $\mathrm{P}$ contents (Table 2). The LREE-enriched samples contain both hornblende and pyroxene gabbros. On the other hand, all flat-REE gabbro samples were of the pyroxene type.

The age of $2117 \pm 4$ Ma reported by Perttunen and Vaasjoki (2001) for the 'Misi gabbro' 

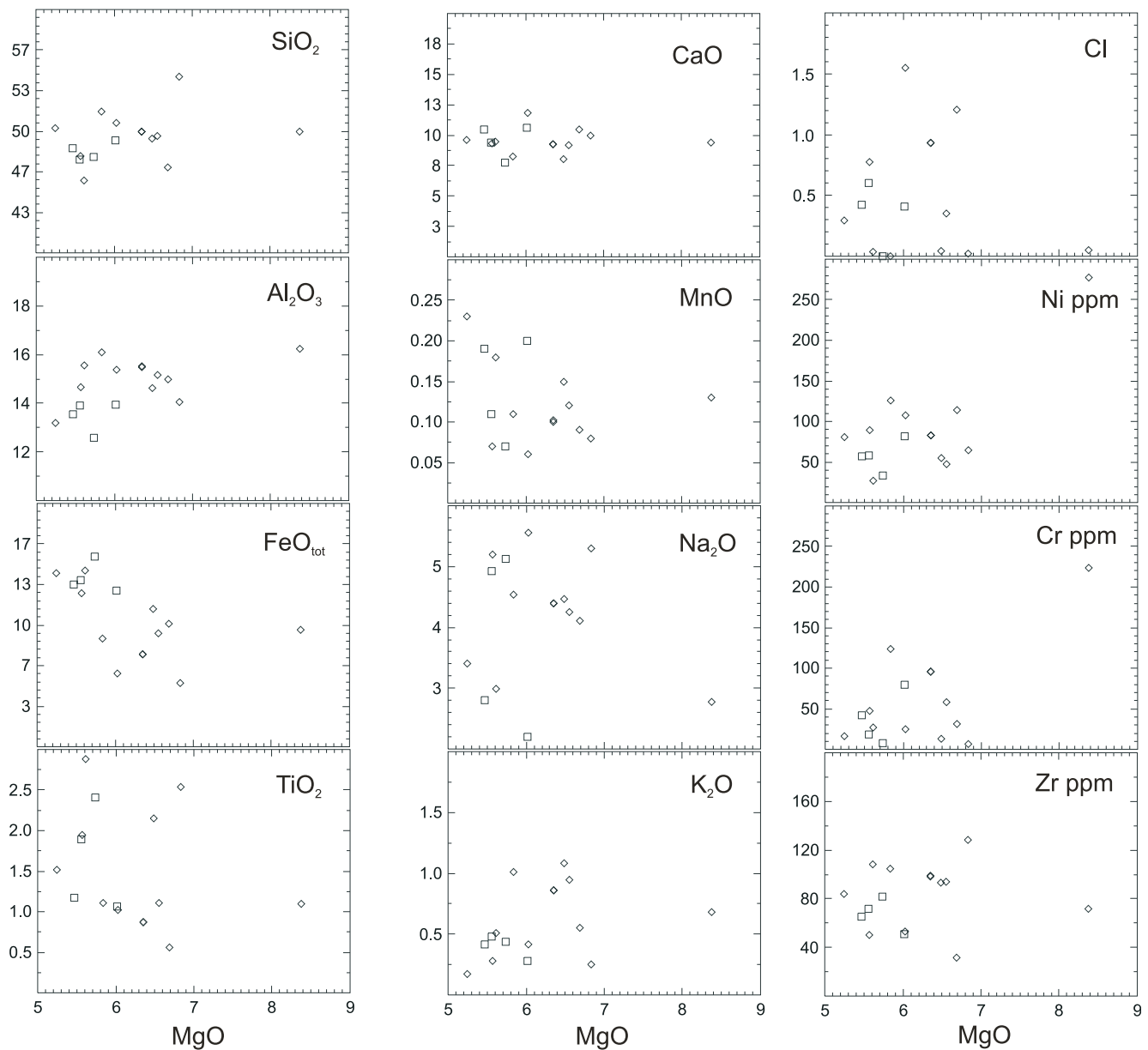

Fig. 5. Bivariant plots for gabbro from the Misi region. Major elements are given as weight percent and trace elements in PPm. Diamonds: LREE-enriched gabbro, squares: MORB-like, flat-REE gabbro.

was determined on the zircons from LREE-enriched hornblende gabbro. The age of the flatREE gabbro is presently unknown; it may be related to the Type 1 mafic lava, which it chemically resembles (Figs. 2A, 2C, 6B and Table 2), but the data yet available do not allow any relative timing constraints.

The relatively high concentrations of $\mathrm{C}, \mathrm{Cl}$, $\mathrm{K}$ and $\mathrm{Na}$ (Tables 2 and 3), and the wide scatter in their concentration (Figs. 3 and 5) is a common feature of nearly all rock types of the Misi region, and is considered to be due to alteration as discussed below.

\subsection{Skarnoids}

A group of heterogeneous, magnesium-rich and silica-poor rocks occur in close association of the magnetite deposits of the Misi region and, in most cases, serve as host rocks for them. In this paper, these rocks are called skarnoids. They can be divided into serpentine rocks, associated with dolomites, and other skarnoids forming a series from actinolite-tremolite rocks to chlorite, talc-chlorite and talc rocks. Serpentine rocks have been detected at Kärväsvaara, Raajärvi and Leveäselkä. Other skarnoids are com- 

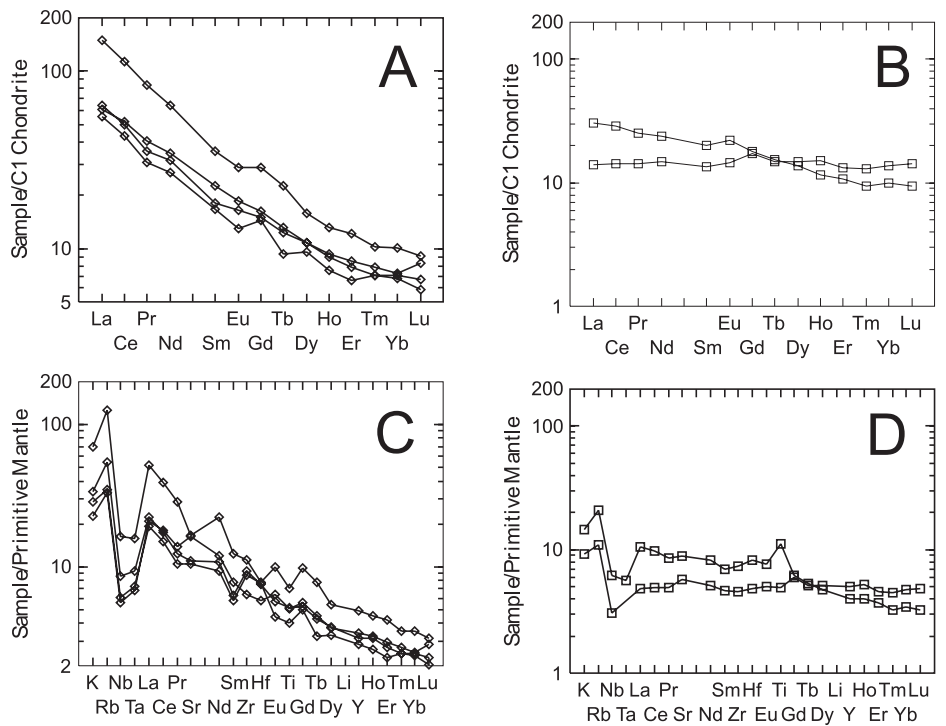

Fig. 6. Chondrite normalised lanthanides of the a) LREEenriched, and b) flat-REE gabbros, c) primitive mantle-normalised incompatible elements of LREE-enriched, and d) flatREE gabbro. Normalising values from Sun \& McDonough (1989). Symbols as in Figure 5. mon around all iron deposits. They also occur as epigenetic veins in quartzite and in the contact zone between quartzite and albitite about 1.5 $\mathrm{km}$ from the NE from the Puro deposit.

Pure serpentine rocks are fine-grained and unfoliated with their colour ranging from black to pale or dark green, reddish brown and yellow. Generally they are devoid of primary textures but, locally, there are chlorite-rich bands, which could indicate the primary layering of their precursor, the dolomitic marbles. According to our XRD work, the main serpentine mineral is lizardite. In addition, chrysotile has been detected (Nuutilainen, 1968). Chlorite, talc and tremolite may also occur as major, and apatite and magnetite as minor minerals in the serpentine rock. In addition, remnants of carbonate have been detected in several samples.

The actinolite-tremolite, talc and chlorite rocks contain, in addition to these minerals, variable amounts of biotite, albite, serpentine, carbonates, apatite, magnetite, pyrite, and chalcopyrite. The dominant amphibole is actinolite. Tremolite only dominates where the rock is in association with dolomite or serpentine rock. Grain size of these skarnoids varies between 0.4 and $1.2 \mathrm{~mm}$ and their texture from nematoblastic to lepidoblastic. They are locally foliat- ed, especially the chlorite-, biotite-, and talcrich ones.

\section{Iron deposits}

All iron deposits in the Misi region (Fig. 1, Table 1) are hosted by skarnoids within a sedimentary sequence consisting of quartzite and dolomitic marble, or by skarnoids within albitite as is the case at Puro. In every case where there is a Fe deposit, the sedimentary unit itself is within or in contact with albitite. The deposits generally are steeply dipping or subvertical lenses or steeply plunging pipes, and typically have an E-W strike (Nuutilainen, 1968). Below, we describe the Raajärvi and Puro deposits in more detail. The major element compositions of the wall rocks are shown in Table 3. The metal content of the Raajärvi and Puro ores, skarnoids, and wall rocks are summarised in Tables 4 and 5.

\section{I. Raajärvi}

The Raajärvi deposit comprises two larger, irregularly-shaped, ore bodies and a few smaller ore bodies (Fig. 7). The ore is hosted by skarnoids, the eastern part of the deposit mainly by serpentine rock and the western part by tremo- 
Table 3. Major element and selected minor element composition of the wall rocks of the Raajärvi and Puro deposits. I: Unaltered dolomitic marble (Raajärvi), 2: Weakly altered dolomitic marble (Raajärvi), 3: Serpentine skarnoid (Raajärvi), 4: Chlorite-talc-serpentine skarnoid (Raajärvi), 5:Actinolite skarnoid (Puro), 6:Actinolite-biotite skarnoid (Puro), 7: Granoblastic albitite (Puro), 8: Granophyric albitite (Raajärvi). XRF data, except for S and C which are analysed by Leco.

\begin{tabular}{|c|c|c|c|c|c|c|c|c|}
\hline & 1. & 2. & 3. & 4. & 5. & 6. & 7. & 8. \\
\hline $\mathrm{SiO}_{2}$ wt. $\%$ & 3.30 & 9.43 & 41.09 & 42.52 & 53.86 & 44.85 & 62.30 & 71.50 \\
\hline $\mathrm{Al}_{2} \mathrm{O}_{3}^{2}$ & 0.67 & 3.12 & 0.92 & 3.76 & 2.11 & 10.37 & 15.70 & 14.90 \\
\hline $\mathrm{TiO}_{2}$ & 0.02 & 0.06 & 0.04 & 0.03 & 0.32 & 0.50 & 1.13 & 0.64 \\
\hline $\mathrm{Fe}_{2} \mathrm{O}_{3}$ tot & 0.68 & 3.67 & 8.32 & 5.02 & 8.58 & 8.14 & 3.70 & 1.36 \\
\hline $\mathrm{MnO}$ & 0.28 & 0.46 & 0.15 & 0.08 & 0.10 & 0.08 & 0.05 & 0.01 \\
\hline $\mathrm{MgO}$ & 21.31 & 21.56 & 37.42 & 33.42 & 18.60 & 18.58 & 4.09 & 2.43 \\
\hline $\mathrm{CaO}$ & 28.85 & 23.61 & 1.37 & 4.70 & 11.05 & 6.67 & 4.15 & 0.54 \\
\hline $\mathrm{Na}_{2} \mathrm{O}$ & $<0.05$ & $<0.05$ & $<0.05$ & $<0.05$ & 0.83 & 0.93 & 8.39 & 7.74 \\
\hline $\mathrm{K}_{2} \mathrm{O}$ & 0.22 & 0.22 & 0.06 & 0.02 & 0.15 & 3.30 & 0.16 & 0.63 \\
\hline $\mathrm{P}_{2}^{2} \mathrm{O}_{5}$ & 0.04 & 0.05 & 0.04 & 0.43 & 0.01 & 0.60 & 0.04 & 0.12 \\
\hline $\mathrm{CO}_{2}$ & 44.71 & 35.95 & 1.14 & 0.59 & $<0.04$ & 0.07 & 0.07 & 0.07 \\
\hline Total & 100.08 & 98.13 & 90.55 & 90.57 & 95.61 & 94.09 & 99.79 & 99.93 \\
\hline $\mathrm{Cl} \mathrm{ppm}$ & 567 & 1198 & 543 & 306 & 238 & 552 & 177 & 164 \\
\hline $\mathrm{Ba}$ & $<20$ & 29 & 30 & 22 & $<20$ & 292 & 46 & 68 \\
\hline $\mathrm{Cr}$ & $<30$ & $<30$ & $<30$ & $<30$ & 50 & 106 & $<30$ & $<30$ \\
\hline $\mathrm{Ni}$ & $<20$ & 23 & 72 & 34 & 132 & 36 & 26 & $<20$ \\
\hline S & $<100$ & $<100$ & $<100$ & $<100$ & $<100$ & $<100$ & $<100$ & $<100$ \\
\hline V & $<10$ & 33 & 116 & 94 & 222 & 142 & 163 & 39 \\
\hline
\end{tabular}

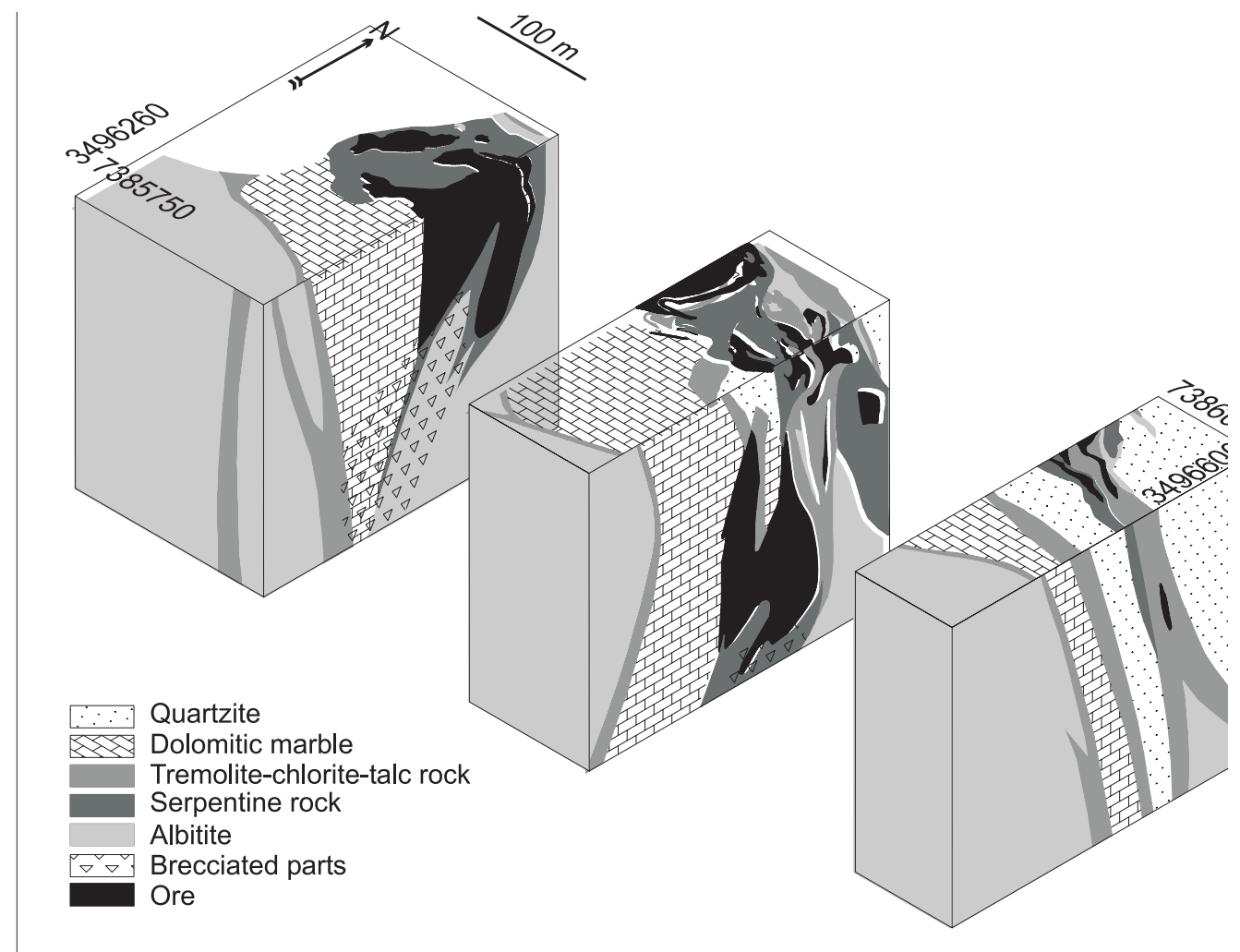

Fig. 7. A block model of the Raajärvi deposit. Oblique view from SE. Coordinate system: Finnish national (KKJ). Edited after Nuutilainen (1968) and unpublished Rautaruukki Oy data. 
Table 4. Chemical composition of wall rocks and ore at Raajärvi. I: Albitite, 2: Weakly altered dolomite, 3: Skarnoids, 4: Ore. ICP-AES data, except for $\mathrm{Au}, \mathrm{Te}, \mathrm{Bi}$, and $\mathrm{Sb}$ which are analysed by GFAAS. Au, Te, Bi and $\mathrm{Sb}$ in Ppb, all other data in Ppm. Averages calculated using $0.5 \times$ detection limit for values below detection limit.

\begin{tabular}{|c|c|c|}
\hline & Min & Average \\
\hline Ag & $<1$ & - \\
\hline As & $<10$ & - \\
\hline $\mathbf{B a}$ & 15 & 30 \\
\hline $\mathrm{Be}$ & $<1$ & 0 \\
\hline Co & 3 & 4 \\
\hline $\mathrm{Cu}$ & $<1$ & 5 \\
\hline $\mathrm{Fe}$ & 4880 & 7240 \\
\hline $\mathbf{L a}$ & 10 & 12 \\
\hline $\mathbf{L i}$ & 2 & 4 \\
\hline $\mathrm{Ni}$ & $<3$ & 3 \\
\hline $\mathbf{P}$ & 413 & 584 \\
\hline $\mathbf{P b}$ & $<10$ & - \\
\hline$S$ & 41 & 292 \\
\hline $\mathrm{Sr}$ & 3 & 4 \\
\hline Th & 10 & 11 \\
\hline V & 8 & 22 \\
\hline $\mathrm{Zn}$ & 7 & 7 \\
\hline $\mathrm{Au}$ & $<0.5$ & 0 \\
\hline $\mathbf{B i}$ & 4 & 22 \\
\hline $\mathrm{Sb}$ & $<5$ & 5 \\
\hline $\mathrm{Te}$ & $<2$ & - \\
\hline
\end{tabular}

Max
$<1$
$<10$
53
1
6
14
8590
15
9
6
723
$<10$
746
6
13
31
8
1
36
16
$<2$

2.

\begin{tabular}{c|cc}
3 & Min & Average \\
3 & $<1$ & - \\
3 & $<10$ & 8 \\
3 & 12 & 55 \\
3 & 4 & - \\
3 & $<1$ & 49
\end{tabular}

3380

16

Max
$<1$
16
155
$<1$
39
10
31100
25
58
25
302
$<10$
350
99
$<10$
49
101
28
183
15
10

Min
$<1$
$<10$
11
$<1$
$<1$
$<1$
801
$<1$
$<1$
$<3$
$<50$
$<10$
51
$<1$
$<10$
2
6
$<0.5$
$<2$
$<5$
$<2$

3.

Average Max

Average
0

327

$90 \quad 420$

12

$20 \quad 101$

$28 \quad 296$

3070091000

$12 \quad 47$

$14 \quad 41$

$41 \quad 335$

$1500 \quad 10100$

250

$570 \quad 4000$

1031

- $\quad<10$

$100 \quad 337$

$31 \quad 107$

$8 \quad 131$

$12 \quad 74$

$10 \quad 36$

\begin{tabular}{c|cccc}
$\mathbf{n}$ & Min & $\begin{array}{c}4 . \\
\text { Average }\end{array}$ & Max & $\mathbf{n}$ \\
23 & $<1$ & - & $<1$ & 16 \\
23 & $<10$ & - & $<10$ & 16 \\
23 & 13 & 47 & 309 & 16 \\
23 & $<1$ & 1 & 2 & 16 \\
23 & 23 & 106 & 480 & 16 \\
23 & 7 & 170 & 1370 & 16 \\
23 & 131000 & 362500 & 516000 & 16 \\
23 & $<1$ & 8 & 47 & 16 \\
23 & 2 & 6 & 22 & 16 \\
23 & $<3$ & 109 & 500 & 16 \\
23 & $<50$ & 1300 & 12900 & 16 \\
23 & $<10$ & 1 & 10 & 16 \\
23 & 59 & 4290 & 34700 & 16 \\
23 & $<1$ & 8 & 31 & 16 \\
23 & $<10$ & - & $<10$ & 16 \\
23 & 34 & 970 & 2390 & 16 \\
23 & 19 & 63 & 126 & 16 \\
23 & $<0.5$ & 58 & 625 & 16 \\
23 & $<2$ & 24 & 104 & 16 \\
23 & $<5$ & 24 & 111 & 16 \\
23 & $<2$ & 48 & 347 & 16
\end{tabular}

lite, tremolite-biotite, tremolite-chlorite, tremolite-chlorite-talc, chlorite-talc and talc rocks. In the deeper parts of the deposit, irregular, 5-20 $\mathrm{mm}$ wide calcite veins brecciate the hosting sequence of dolomitic marble and skarnoids, and the ore (Fig. 7). Calcite also occurs as small cavity fillings. Haematite, talc, chlorite and small amounts of baryte occur together with calcite. Replacement of magnetite by haematite is common in the brecciated parts of the ore. Tremolite and the early serpentine have been partially to completely replaced by late serpentine close to the breccia veins.

Most of the ore is massive magnetite rock which consists of variably martitised magnetite with a grain size of $0.05-0.5 \mathrm{~mm}$. The degree of martitisation is locally high, especially in areas where late-stage calcite brecciates the ore. In addition, there are small volumes of disseminated ore in the marble and in the skarnoids. Other ore minerals present are pyrite with minor chalcopyrite and occasional bornite. In deformed parts of the ore, sulphides show signs of remobi- lisation. The gangue comprises serpentine (lizardite), amphibole (tremolite-actinolite), chlorite, talc, calcite, dolomite and apatite. The amount of sulphides is low with the $S$ concentration varying from 0.001 to $3.47 \mathrm{wt} . \%$ (Table 4). According to Nuutilainen (1968), the average $S$ content of the ore is $0.1 \mathrm{wt} . \%$. The highest concentrations of sulphides were detected in ore samples near the contact to weakly altered marble, whereas the serpentine rock-hosted parts of the ore are generally devoid of any sulphide.

The ore is weakly enriched in P, S, and V, and locally slightly in $\mathrm{Co}, \mathrm{Cu}, \mathrm{Ni}, \mathrm{Au}$, and $\mathrm{Te}$ compared to its albitite and weakly altered marble wall rocks (Table 4). Enrichment of elements is similar, but weaker, in skarnoids.

\subsection{Puro}

The Puro deposit is about $2 \mathrm{~km}$ to the east from Raajärvi, in the same lithological sequence as the latter. The surface geology of the Puro area is shown in Figure 8. The major difference be- 


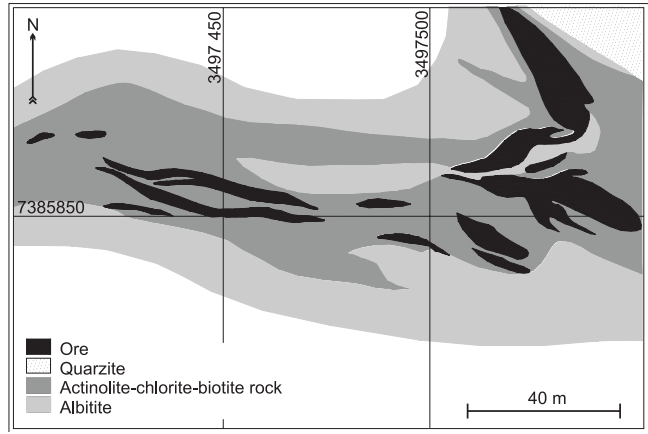

Fig. 8. Surface geology of the Puro deposit. Coordinate system: Finnish national (KKJ). Edited after Nuutilainen (1968) and unpublished Rautaruukki Oy data.

tween Puro and Raajärvi is the lack of dolomite and serpentine rock at Puro where the ore is hosted by actinolite, actinolite-biotite, actinolite-chlorite and chlorite rocks. Albitites and albitised quartzites as wall rocks are identical to those at Raajärvi.

The Puro ore comprises weakly martitised magnetite with small amounts of pyrite, chalcopyrite and pyrrhotite. The amount of sulphides varies but, generally, they are slightly more abundant than at Raajärvi. As at Raajärvi, the sulphides have been remobilised in the deformed parts of the deposit. Gangue comprises actinolite, chlorite, biotite and talc with small amounts of apatite and quartz. The ore is dominantly banded, less frequently massive. Grain size of the magnetite is $0.4-1.0 \mathrm{~mm}$, and the texture granoblastic.

Compared to its albitite wall rocks, the Puro ore shows a slight enrichment in P, S, and V and very weak and local enricment in $\mathrm{Co}, \mathrm{Cu}$, and Te (Table 5). As at Raajärvi, the skarnoid wall rocks show similar, but weaker enrichment of elements as the ore compared albitite wall rock.

\section{Alteration in the Misi region}

Alteration in the Misi region comprises 1) regional scale, low to moderate intensity, $\mathrm{Na} \pm \mathrm{Cl}$ alteration (scapolisation and albitisation), 2) local intense $\mathrm{Na} \pm \mathrm{Cl}$-alteration (albitisation), 3) local $\mathrm{Ca}-\mathrm{Fe}-\mathrm{Mg}$-alteration (formation of the magnetite ores and associated skarnoids), 4) hydrolytic alteration (serisitisation) and silicification associated with major shear zones, and 5) local $\mathrm{Ca}-\mathrm{CO}_{2}$ alteration (carbonate veining and carbonatisation). The schematic sequence of deformation stages, alteration events and igneous activity in Misi area is shown in Figure 9.

\section{I. Scapolitisation}

Scapolitisation, commonly accompanied with low- to moderate-degree albitisation, is a common feature in nearly all rocks in the region. Only the mica gneisses in the SW flank of the belt, granitoids, and granite- and pegmatite dykes are totally devoid of any signs of the $\mathrm{Na}-$ $\mathrm{Cl}$ alteration. Chemical compositions from even the least-altered rocks show anomalous concentrations of $\mathrm{Cl}$, except in arkosite and granite, and relatively high $\mathrm{Na}$ contents for all rock types (Table 2). Especially high concentrations of $\mathrm{Cl}$ have been detected in the gabbros reflecting their high scapolite content.

Scapolite forms porphyroblasts, smaller individual grains replacing plagioclase, and veins together with albite and magnetite. Scapolite is generally Na-rich, marialitic, in composition. In places, especially in the calc-silicate interlayers of mafic tuffs or tuffites, its composition is more meionitic, reflecting the more Ca-rich bulk composition of the host rock. In all gabbros, scapolite is marialitic, does not form porphyroblasts, but small individual grains or clusters of grains replacing plagioclase, and is of nearly same colour as plagioclase. Scapolite-albite \pm magnetite \pm pyrite \pm chalcopyrite veins occur locally in albitised gabbros, and in albitites. Composition of scapolite in these veins is marialitic.

\subsection{Albitisation}

Albitisation in the Misi region is not a single event, rather a series of events over a period of time (Figs. 9-11). We have divided albitisation into two stages and refer to them as "early", weak to moderate albitisation and 'later', intense albitisation. 
Table 5. Chemical composition of wall rocks and ore at Puro. I:Albitite, 2: Skarnoids, 3: Ore. ICP-AES data, except for $\mathrm{Au}, \mathrm{Te}, \mathrm{Bi}$, and $\mathrm{Sb}$ which are analysed by GFAAS. $\mathrm{Au}, \mathrm{Te}, \mathrm{Bi}$ and $\mathrm{Sb}$ in Ppb, all other data in ppm. Averages calculated using $0.5 \times$ detection limit for values below detection limit.

\begin{tabular}{|c|c|c|c|}
\hline & Min & Average & $\operatorname{Max}$ \\
\hline $\mathrm{Ag}$ & $<1$ & - & $<1$ \\
\hline As & $<10$ & - & $<10$ \\
\hline Ba & 11 & 14 & 18 \\
\hline $\mathrm{Be}$ & $<1$ & - & $<1$ \\
\hline Co & 4 & 11 & 20 \\
\hline $\mathrm{Cu}$ & $<1$ & 12 & 39 \\
\hline $\mathbf{F e}$ & 6220 & 27073 & 54100 \\
\hline La & 13 & 24 & 47 \\
\hline $\mathbf{L i}$ & $<1$ & 2 & 5 \\
\hline $\mathrm{Ni}$ & 3 & 6 & 9 \\
\hline $\mathbf{P}$ & 664 & 1329 & 1830 \\
\hline $\mathbf{P b}$ & $<10$ & - & $<10$ \\
\hline$S$ & 26 & 65 & 127 \\
\hline Sr & 3 & 4 & 5 \\
\hline Th & $<10$ & 3 & 13 \\
\hline V & 25 & 85 & 217 \\
\hline $\mathrm{Zn}$ & 4 & 6 & 6 \\
\hline Au & $<0.5$ & 22 & 69 \\
\hline $\mathbf{B i}$ & 6 & 12 & 22 \\
\hline Sb & $<5$ & 13 & 40 \\
\hline $\mathrm{Te}$ & $<2$ & 2 & 7 \\
\hline
\end{tabular}

2.

\begin{tabular}{|c|c} 
Min \\
$<1$ \\
$<10$ \\
10 \\
$<1$ \\
2 \\
$<1$ \\
1920 \\
$<1$ \\
2 \\
4 \\
$<50$ \\
$<10$ \\
24 \\
$<1$ \\
$<10$ \\
6 \\
5 \\
$<0.5$ \\
$<2$ \\
$<5$ \\
$<2$
\end{tabular}

$\begin{array}{cc}\text { Average } & \text { Max } \\ - & <1 \\ - & <10 \\ 65 & 184 \\ 0 & 1 \\ 19 & 41 \\ 8 & 45 \\ 26816 & 53200 \\ 14 & 32 \\ 12 & 29 \\ 41 & 96 \\ 596 & 1790 \\ - & <10 \\ 217 & 969 \\ 5 & 14 \\ - & <10 \\ 78 & 170 \\ 13 & 23 \\ 1 & 9 \\ 6 & 16 \\ - & <5 \\ 8 & 23\end{array}$

3.

$\begin{array}{cccc}\text { Min } & \text { Average } & \text { Max } & \mathbf{n} \\ <1 & - & <1 & 8 \\ <10 & - & <10 & 8 \\ 16 & 24 & 48 & 8 \\ <1 & 1 & 1 & 8 \\ 19 & 115 & 221 & 8 \\ <1 & 217 & 548 & 8 \\ 114000 & 403375 & 580000 & 8 \\ 1 & 12 & 42 & 8 \\ <1 & 7 & 14 & 8 \\ 14 & 190 & 650 & 8 \\ 95 & 2875 & 14400 & 8 \\ <10 & - & <10 & 8 \\ <20 & 12242 & 32700 & 8 \\ 2 & 10 & 34 & 8 \\ <10 & - & <10 & 8 \\ 43 & 605 & 1280 & 8 \\ 13 & 21 & 37 & 8 \\ <0.5 & 8 & 51 & 8 \\ 6 & 31 & 76 & 8 \\ <5 & 1 & 10 & 8 \\ 3 & 93 & 275 & 8\end{array}$

\begin{tabular}{|c|c|c|c|c|}
\hline $\begin{array}{l}\text { Tectonic environment } \\
\text { Dominant } \sigma_{1} \text { direction } \\
\text { Deformation stage }\end{array}$ & $\begin{array}{c}\text { Extensional } \\
\qquad \text { pre- } D_{1}\end{array}$ & $\begin{array}{l}\text { Compressional } \\
\qquad \begin{array}{c}\mathrm{N}-\mathrm{S} \\
\mathrm{D}_{1}\end{array}\end{array}$ & $\begin{array}{l}\text { Compressional } \\
\qquad \begin{array}{c}\text { NE-SW } \\
D_{2}\end{array}\end{array}$ & $\begin{array}{c}\text { Compressional } \pm \\
\text { Extensional } \\
\mathrm{E}-\mathrm{W} \\
\mathrm{D}_{3}\end{array}$ \\
\hline Regional albitisation & 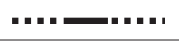 & & & \\
\hline Intense albitisation & $\because$ & & & \\
\hline Formation of scapolite & $\longrightarrow$ & $\cdots$ & 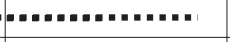 & \\
\hline Formation of skarnoids & $\because ? \cdot-\quad \cdot$ & & & \\
\hline Formation of magnetite ores & $-\cdot$ & & & \\
\hline Serisitisation & & & - & \\
\hline Carbonatisationon and carbonate veining & & & $\cdots$ & 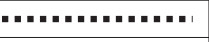 \\
\hline Intrusive activity & $\longrightarrow$ & & 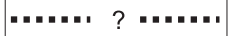 & \\
\hline
\end{tabular}

Fig. 9. Schematic sequence of deformation stages, alteration and igneous activity in the Misi region. The pre- $D_{1}$ intrusives consist of the ca. 2I 20 Ma (Perttunen \& Vaasjoki, 200I) LREE-enriched gabbros. The earliest compressional deformation stage $\left(D_{1}\right)$ in northern Finland has been dated at 1930-1900 Ma (Sorjonen-Ward, 1995; Hanski et al., 1997). Synorogenic $\left(D_{2}\right)$, ca. 1890 Ma Haaparanta suite intrusives (Perttunen \& Vaasjoki, 200I) occur in western part of the Peräpohja Schist Belt, but have not been detected in the Misi region. Late orogenic (I750 Ma, Lauerma, 1982) granitoids represent the intrusives of the $D_{3}$.

The early albitisation is conformable with the primary structures, such as layering in tuffs and breccia structures in lavas (Figs. 10 and 11). Formation of epidote, together with scapolite and albite, is a common feature. Magnetite has also been formed locally, together with the albite.
Later, intense albitisation is concentrated in E-W trending shear or fault zones. This style of alteration is pervasive and seems not to follow any primary structures. Intense albitisation has affected gabbros, mafic lavas, quartzites, and arkosites. In places, especially in the wall rocks 


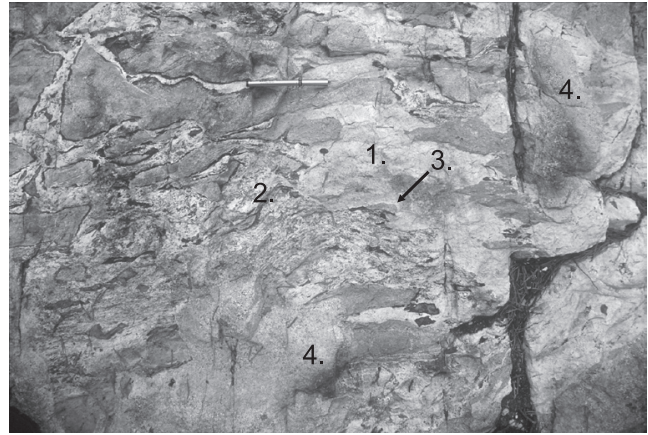

Fig. 10. Twice-albitised mafic lava breccia. I: intensely albitised zone overprinting earlier, moderately albitised parts of breccia, 2: the early albitisation mainly focussed on breccia matrix, 3: intense albitisation overprints both the earlier albitised matrix and breccia fragments, 4 : patches of granitoid dykes postdating all alteration. The pen is $13 \mathrm{~cm}$ long.

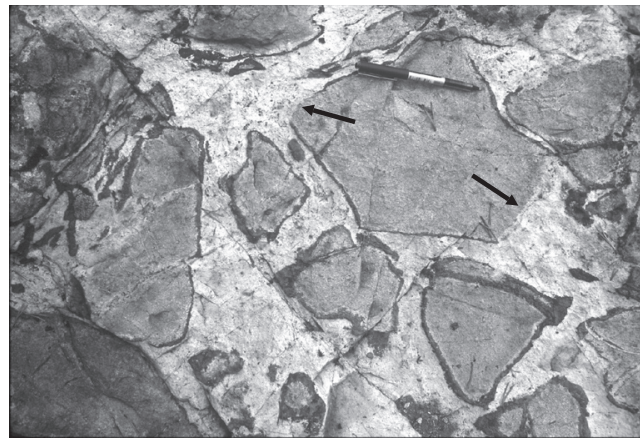

Fig. I I. Albitised volcanic breccia. Arrows indicate locations where the pale grey albite, related to the intense albitisation, replaces the dark hornblende-rich margins of the breccia fragments. The pen is $13 \mathrm{~cm}$ long.
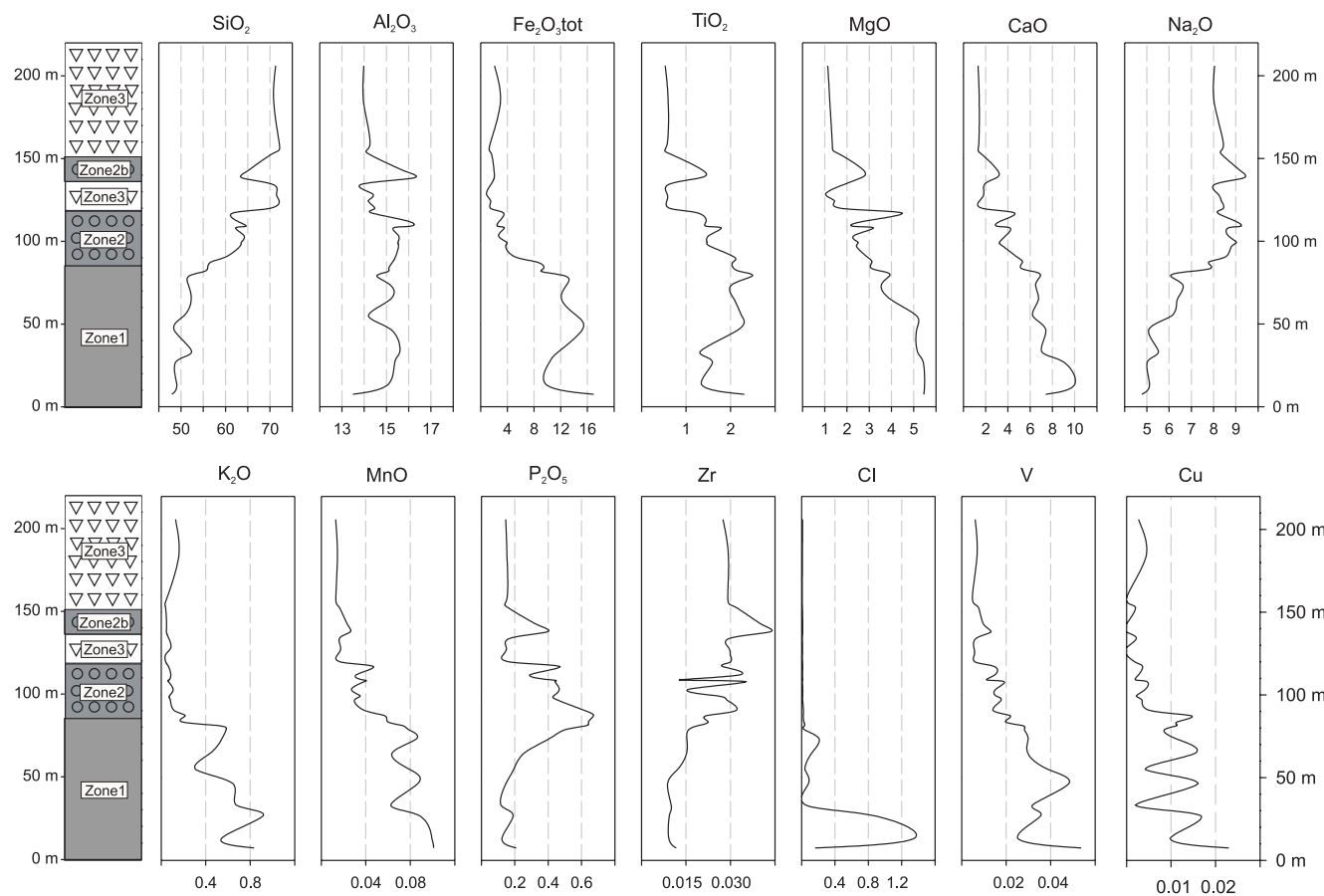

Fig. I2. Geochemical profile along drill core R37 at Puro. All concentrations in wt.\%.

of the magnetite deposits, intense albitisation has completely destroyed the primary structures, textures and strongly modified the chemical composition making it difficult to recognise the protolith.
Irrespective of whether the albitisation has been weak or intense, the composition of the primary plagioclase has been shifted to more albitic. Biotite and hornblende have been replaced by albite. Magnetite, as well as any primary sul- 

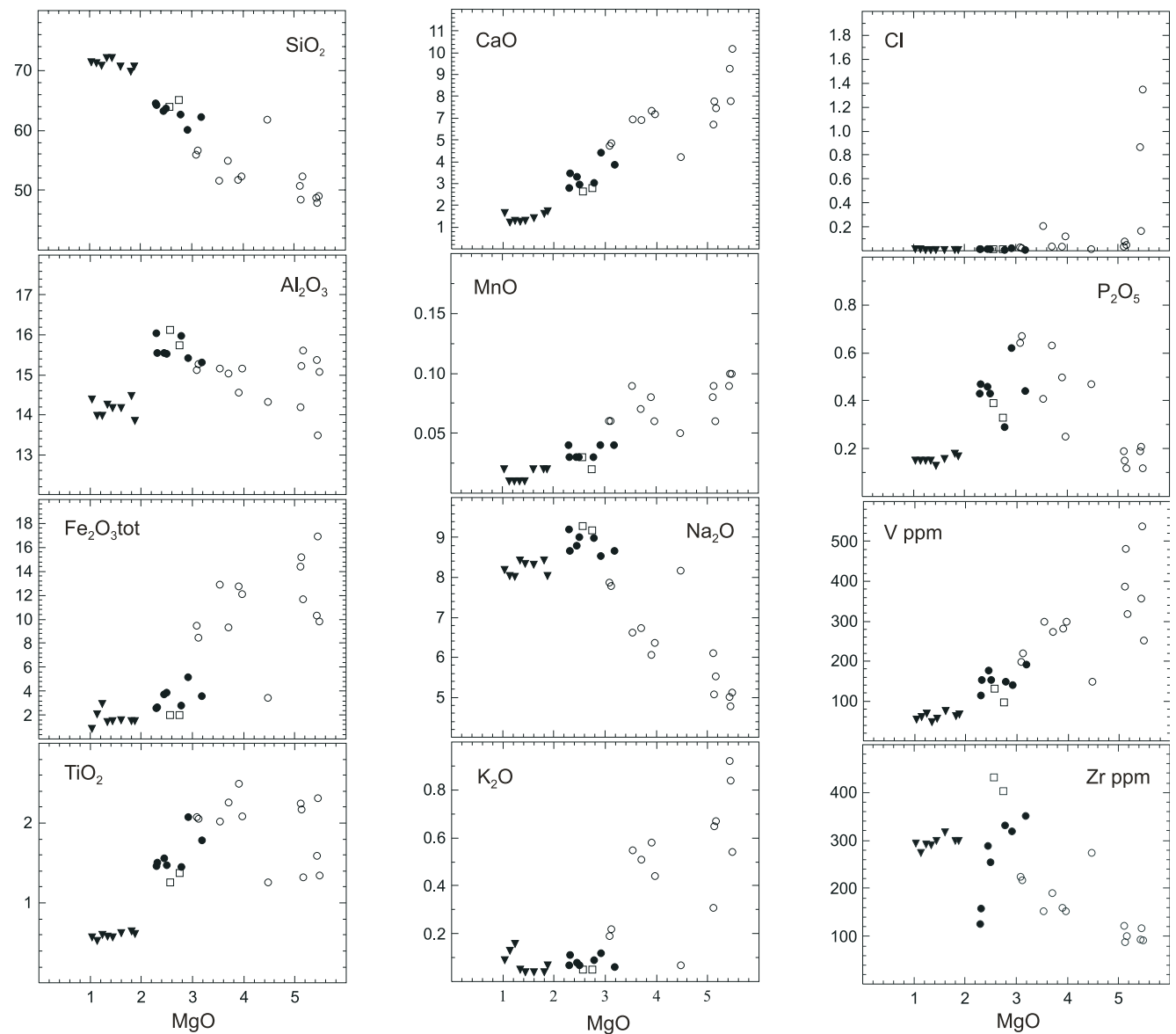

Fig. I 3. Bivariant plots for the samples from drill core R37. All elements as wt.\% except $\mathrm{V}$ and $\mathrm{Zr}$ which are given as Ppm. Open and filled circles from zones $I$ and 2 , squares from zone $2 b$, filled triangles from zone 3.
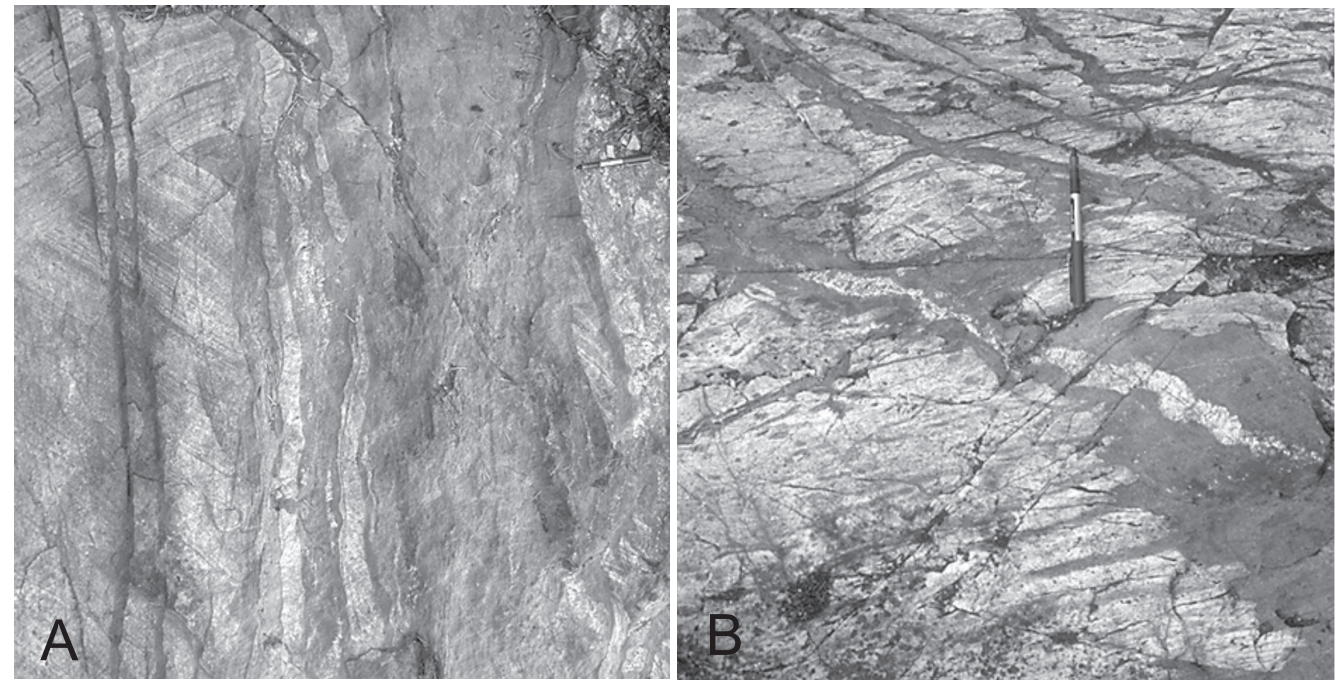

Fig. 14. a) Actinolite veins (dark) cutting across primary sedimentary structures in quartzite. The pen is $13 \mathrm{~cm}$ long, b) Actinolite vein network (dark) in quartzite. Thickest vein has an albite-rich core (pale) 
phide, mainly pyrite and chalcopyrite, are destroyed in the more intensely albitised rocks. Titanite has been formed at the expense of Tibearing silicates and oxides.

In the Raajärvi-Puro area, the pure albitites are grey or, more commonly, pink rocks consisting of albite and minor or trace amounts of titanite, biotite, amphibole, quartz and apatite. Their texture varies from granoblastic to granophyric and porphyritic. The grain size is $0.3-$ $1.0 \mathrm{~mm}$ in granoblastic type, and $0.5-2.0 \mathrm{~mm}$ for phenocrysts and $0.04-0.2 \mathrm{~mm}$ for groundmass in the porphyric type. Granophyric texture has locally been detected between larger albite grains in highly albitised quartz-bearing rocks.

In places, a gradual change from gabbro to albitite can be observed in outcrop and in drill core, for example in the core R37, next to the Puro deposit. At Matkavaara, a few hundred meters NE of the Puro deposit, a scapolite-bearing gabbro passes into albitite within a distance of 150 meters. Vertical variation of selected elements in 30 samples from the drill core R37 is presented in Figure 12. In Figure 13, the same analyses are shown in bivariant plots. The geochemistry of this sequence and its significance is discussed below.

\subsection{Skarnification}

Skarnification is observed in areas where also intense albitisation has taken place. Major element compositions of selected skarnoid samples are shown in Table 3. Tables 4 and 5 show the average metal content of the skarnoids from the Raajärvi and Puro deposits.

Serpentine rocks are restricted to the areas where the dolomitic marbles occur, and only the Puro deposit is totally devoid of serpentine rocks. In many localities in the Misi region (e.g., at Raajärvi), serpentinisation is accompanied with formation of tremolite, tremolitechlorite and chlorite rocks. The actinolite rock also forms veins in narrow E-W trending shear zones in quartzite, especially in the contact zone between albitite and quartzite (Fig 14).
Table 6. Chemical composition of albitised arkose and intensely sericitised, previously albitised, arkose from the NW-SE trending major shear zone on the eastern flank of the Misi region. XRF data, except for $\mathrm{S}$ and $\mathrm{C}$ which are analysed by Leco.

\begin{tabular}{|c|c|c|}
\hline & 1. & 2. \\
\hline $\mathrm{SiO}$ wt. $\%$ & 72.02 & 81.39 \\
\hline $\mathrm{Al}_{2} \mathrm{O}_{3}^{2}$ & 16.15 & 11.59 \\
\hline $\mathrm{TiO}_{2}^{2}$ & 0.17 & 0.08 \\
\hline $\mathrm{Fe}_{2} \mathrm{O}_{3}$ tot & 1.24 & 1.55 \\
\hline $\mathrm{MnO}^{2}$ & 0.02 & 0.01 \\
\hline $\mathrm{CaO}$ & 2.66 & 0.02 \\
\hline $\mathrm{MgO}$ & 0.43 & 0.32 \\
\hline $\mathrm{Na}_{2} \mathrm{O}$ & 4.44 & 0.22 \\
\hline $\mathrm{K}_{2} \mathrm{O}$ & 2.59 & 3.75 \\
\hline $\mathrm{P}_{2}^{2} \mathrm{O}_{5}$ & 0.05 & 0.01 \\
\hline $\mathrm{CO}_{2}^{3}$ & 0.01 & $<0.01$ \\
\hline Total & 99.78 & 98.94 \\
\hline $\mathrm{Ba}$ & 306 & 420 \\
\hline $\mathrm{Cl}$ & 131 & $<100$ \\
\hline $\mathrm{Cr}$ & $<30$ & $<30$ \\
\hline $\mathrm{Cu}$ & $<20$ & $<20$ \\
\hline $\mathrm{Ni}$ & $<20$ & $<20$ \\
\hline $\mathrm{Rb}$ & 76 & 184 \\
\hline S & $<100$ & 590 \\
\hline $\mathrm{Sr}$ & 129 & $<10$ \\
\hline V & $<10$ & $<10$ \\
\hline Y & $<10$ & 11 \\
\hline $\mathrm{Zr}$ & 121 & 104 \\
\hline
\end{tabular}

\subsection{Sericitisation and silicification}

In the NW-trending shear zone at the NE boundary of the Misi region, the previously albitised arkosites are sericitised and silicified. Here, quartz and coarse-grained sericite replace albitic plagioclase and fine-grained biotite. Quartz veining and small amounts of sulphides also characterise the sericitised rocks. Locally, silicification is very intense and can be described as silica flooding. The mineral reactions described above are typical for hydrolytic metasomatism, more precisely sericitisation (Barton et al., 1991 and references therein). Chemical composition of albitised arkose and sericitised, previously albitised, arkose are shown in Table 6.

\subsection{Late stage carbonate veining and carbon- atisation}

At Raajärvi, intense brecciation and associated carbonatisation is locally present in deeper parts 
of the magnetite deposit and its wallrocks (Fig. 7). In these areas, calcite veins brecciate magnetite ore, albitite, serpentine rock and other skarnoids. There, the brecciated magnetite has been replaced by haematite and, locally, the calcite veins contain idiomorphic haematite crystals. In serpentine-rich rocks, the calcite veining is related to recrystallisation of serpentine minerals and second-stage serpentinisation of amphibole.

\section{Discussion}

\section{I. Igneous and sedimentary rocks}

Due the complicated structure and scarcity of age data, the stratigraphic interpretation of the Misi region is difficult. Archaean basement or basal conglomerates, which are typical for the lower part of the stratigraphy of Peräpohja Schist Belt, have not been found at Misi. What can be said with some confidence, is that the quartzite-dolomite sequence is older than ca. $2120 \mathrm{Ma}$, the intrusion age of the LREE-enriched gabbros. The positive carbon isotope excursion recorded for Palaeoproterozoic carbonate rocks was assigned by Karhu \& Holland (1996) to a time interval between 2220 and $2060 \mathrm{Ma}$, using a dolomite from Misi as one of the three samples defining the older age limit. However, the inferred ages for the utilized sedimentary rocks render the lower age limit somewhat uncertain. Globally, the anomaly may be represented at least by three peaks within a time interval of 2400 to $2060 \mathrm{Ma}$ (Melezhik et al., 1999). In the western part of the Peräpohja Schist Belt, quartzites beneath the major dolomite beds are in many places intruded by ca. 2220 Ma sills (Vaasjoki \& Perttunen, 2001), but nowhere in the Peräpohja Belt have dolomitic beds been seen cut by mafic intrusions of that age. It thus seems probable that dolomitic rocks are younger than ca. 2220 $\mathrm{Ma}$ and, at least in the Misi region, older than ca. 2120 Ma.

Based on carbon isotope data and relationship between the gabboic intrusions and the sedimentary units, we correlate the quartzites and dolomites of the Misi region to the Kiva- lo Group quartzites and dolomites in the western part of the Peräpohja Schist Belt (Perttunen, 1980 ; 1985). Geochemically and volcanologically similar counterparts can also be found in the Kivalo Group for the amygdaloidal, LREEdepleted, mafic volcanic rocks of the Misi region. These are the Jouttiaapa Formation mafic volcanics, for which Huhma et al. (1990) reported a $\mathrm{Sm}-\mathrm{Nd}$ isochron age of $2.09 \pm 70 \mathrm{Ma}$. We regard the black schist-bearing tuffite and tuff unit as belonging to the youngest supracrustal rocks of the Misi region, because graphitebearing schists occur high in the stratigraphy elsewhere in the Peräpohja Schist Belt. Arkosic sediments on both sides of the Misi region poses a serious dating problem, as a surprisingly young age, ca. $1980 \mathrm{Ma}$, has been obtained for detrital zircons from an analogous rock type 55 kilometers west of Misi (Perttunen \& Vaasjoki, 2001; Perttunen et al., 1996).

The granitoids and pegmatites in the northern part of the Misi region evidently belong to the ca. $1800 \mathrm{Ma}$ late- or post-orogenic granitoid group of the Central Lapland Granitoid Complex (Hanski et al., 2001).

The geochemistry of the scapolite gabbro-albitite sequence from drillcore R37 (Figs. 12 and 13) shows that LREE-enriched gabbros are in places highly evolved with the behaviour of major elements and minor elements, including $\mathrm{Zr}$ and $\mathrm{V}$, being very typical for the upper parts of differentiated mafic intrusions with granophyric roof zones (e.g., Wagner \& Brown 1968, Mutanen 1997). We suggest that the zone 1 in Figure 13 is differentiated gabbro and the upper part of the zone 1 represents residual magma (rise in $\mathrm{P}$ and $\mathrm{Zr}$ ). The zone 2 is a hybrid part of the intrusion with increasing amounts of wall rock assimilation (rise in $\mathrm{Si}$, drop in $\mathrm{K}, \mathrm{Mn}$ and $\mathrm{V}$, highly variable $\mathrm{Mg}, \mathrm{Ca}, \mathrm{Zr}, \mathrm{P}$ ). The zone 3 is a granophyric roof of the intrusion (distinctly high Si, $\mathrm{Na}, \mathrm{Zr}$ and low $\mathrm{Al}, \mathrm{Ti}, \mathrm{Ca}, \mathrm{Mn}, \mathrm{P})$. The geochemistry of the zone $2 \mathrm{~b}$ is similar to that of the zone 2; hence, we suggest that it is a dyke or enclave of hybrid material inside of the granophyre. Behaviour of sodium partly follows the trend typical for these systems, but the values are 
quite extreme especially in zones 3 and $2 \mathrm{~b}$. We suggest that this is due to sodic alteration that succeeded the intrusion of the gabbro.

\subsection{Alteration}

Different styles of scapolisation in the Misi region (porphyroblastic, non-porphyroblastic, veining) suggest that scapolite may have formed in more than one stage (Fig. 9). Porphyroblastic scapolite is most obviously a metamorphic feature. Scapolite porphyroblasts are commonly found in the mafic tuffite sequence and their composition is generally meionitic. Abundant non-porphyroblastic scapolite and scapolite in veins in altered gabbros is more marialitic and related to metasomatism during or after the intrusion of gabbros. The presence of marialitic scapolite suggests, that the associated fluids were saline (e.g., Orville, 1974; Ellis, 1978; Vanko \& Bishop, 1982).

Albitisation in the Misi region obviously occurred in several stages (Figs. 9-11). In mafic tuffs and tuffites, early albitisation took place prior to major deformation as the albitised layers have been folded in the $\mathrm{D}_{1}$ stage. In mafic lava breccias, early albitisation is overprinted by intense albitisation (Figs. 10 and 11). In addition to mafic volcanic rocks, the intense albitisation has affected arkoses, gabbros, granophyres, and the hybrid rocks related to the gabbros. This stage is clearly structurally controlled, possibly related to faulting before or during the $\mathrm{D}_{1}$ stage. In any case, it took place after the intrusion of the LREE-enriched gabbros.

The skarnoids formed through metasomatic alteration and metamorphism of dolomitic marble, quartzite, mica schists and tuffite. The field evidence (Fig. 15) and the similar, low $\mathrm{Cr}$ and $\mathrm{Ni}$ contents of the marbles and serpentine rocks (Table 3) demonstrate that the latter were formed by alteration of the former. Fluid inclusion studies on the Raajärvi and Puro deposits indicate the presence of highly saline $\mathrm{H}_{2} \mathrm{O}$ $\mathrm{NaCl}{ }_{ \pm} \mathrm{CaCl}_{ \pm} \mathrm{CO}_{2}$ fluids during the skarnification and ore formation (Niiranen \& Poutiainen, 2003). The chemical compositions of unal-

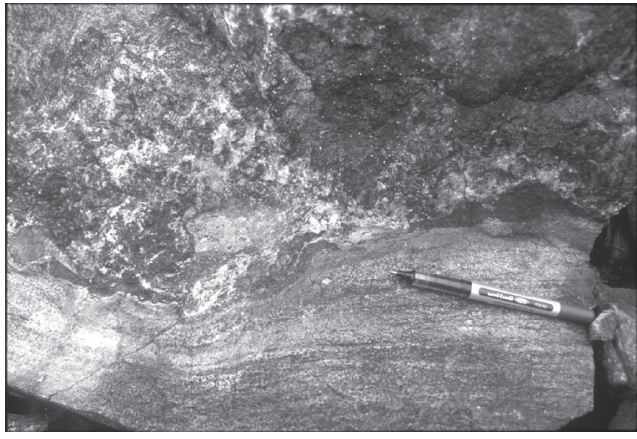

Fig. I5. Alteration front in dolomitic marble at Raajärvi. Banded marble (lower part) is replaced by magnetite (black), serpentine, chlorite, tremolite (dark) and calcite (pale). The pen is $13 \mathrm{~cm}$ long.

tered marble and serpentine rock (Table 3) suggests introduction of $\mathrm{Si}$ and $\mathrm{Fe}$ and extraction of $\mathrm{Ca}$ and $\mathrm{CO}_{2}$ during alteration. The roughly 10 $\%$ decrease in the oxide sum of serpentine rocks compared to unaltered dolomitic marble (Table 3 ) is evidently due to increase in $\mathrm{H}_{2} \mathrm{O}$. Mineralogically, the chemical change is explained as replacement of dolomite with skarn minerals and magnetite.

The skarnoids and the magnetite ore have been deformed at least in two stages; ductile folding has been detected in banded magnetite ore in Puro waste rock piles. Later brittle deformation of the skarnoids, as well as the ores, has been noted on drillcores and on waste rock piles of both Puro and Raajärvi deposits. The occurrence of E-W trending epigenetic skarnoid veins and the deformation history of the skarnoid wall rocks and the ores suggest that skarnification has occurred before the $\mathrm{D}_{2}$, possibly during pre- or syn- $\mathrm{D}_{1}$ faulting or shearing (Fig. 9).

The third recognised alteration style in the Misi region is sericitisation detected in a major shear zone on the eastern flank of the belt. Comparison of the compositions of albitised arkose and subsequently sericitised arkose (Table 5) shows that enrichment of $\mathrm{Si}, \mathrm{Fe}, \mathrm{K}, \mathrm{Rb}$, $\mathrm{Ba}$ and $\mathrm{S}$, and depletion of $\mathrm{Ca}, \mathrm{Na}, \mathrm{Sr}$ and $\mathrm{Cl}$ are related to sericitisation. The changes in generally immobile $\mathrm{Al}, \mathrm{Ti}$ and $\mathrm{Zr}$ (Lesher et al., 1986; Sturchio et al., 1986; MacLean and Kranidiotis, 1987; Bornhorst \& Rasilainen, 1993) suggest 
net mass gain, however the ratios between these elements vary in such a degree that the variation is at least partly primary in nature. Dextral folding is a common feature on both sides of the sericitised shear zone suggesting a dextral sense of the shear. Therefore, the sericitisation probably is related to the $\mathrm{D}_{2}$ stage of deformation. This is also supported by the brittle-ductile nature of the deformation related to sericitisation. Were sericitisation related to $\mathrm{D}_{3}$, we would be able to connect a purely brittle style of deformation with the alteration.

Low-degree carbonatisation is the latest event in the alteration history of the Rajärvi and Puro areas. It is related to brittle deformation suggesting contemporanity with the $\mathrm{D}_{3}$. Intense martitisation of magnetite and carbonatisation suggest the presence of $\mathrm{CO}_{2}$-rich, oxidising, fluids during this stage of alteration.

\subsection{Iron deposits}

The iron deposits studied show a close spatial relationship to quartzite-marble sequence, as well as to albitites formed due to sodic alteration of highly evolved gabbroic rocks. Besides $\mathrm{Fe}$, the ores contain only minor amounts of $\mathrm{P}$, $\mathrm{V}$ and S. Local sulphide-rich parts of the magnetite ores also show trace amounts of $\mathrm{Au}, \mathrm{Co}$, $\mathrm{Cu}$, and $\mathrm{Te}$.

The alteration features, geochemistry and mineralogical constraints of the iron ores presented above suggest that the ores are either: 1) metamorphosed syngenetic ironstones, 2) $\mathrm{Mg}$ Fe-skarns (sensu stricto) formed as a result of contact metasomatism of gabbros, or 3) epigenetic ironstones.

Lithological succession, local banding and low amount of sulfides in the iron deposits are fairly similar to the so called skarn iron ores that occur in central and northern Sweden, and which have been interpreted as metamorphosed chemical sediments (e.g. Frietsch, 1980, 1982, 1984; Frietsch et al., 1995). However, the sodic alteration is not associated with the Swedish skarn iron ores in the scale and intensity as it is with the deposits in Misi region, although it can be present as a regional feature. Also, the Swedish skarn iron deposits do not always show a clear relation to intrusive rocks.

The local banding detected at Raajärvi and Puro could represent primary sedimentary layering. However, banding can also be formed in alteration systems developed in actively deforming environments (e.g. Appleby \& Williams, 1988), and therefore it cannot be considered an conclusive evidence for syngenetic nature of the ironstones. In addition, for example at Raajärvi, the ore is more commonly massive than banded. The consistently close association of gabbros and intensely albitised rocks with the iron deposits in the Misi region can hardly be coincidental.

The Raajärvi and Puro deposits lack hightemperature skarns (i.e. diopside-, olivine- and garnet-rich rocks), but their presence as precursor to the serpentine- or tremolite-rich skarnoids cannot be excluded. It is possible that such high temperature skarns (sensu stricto) were formed as a result of contact metamorphism and metasomatism of gabbros, and that the present skarnoids represent products of retrograde alteration of them.

Although the iron deposits of the Misi region show only trace amounts of $\mathrm{Co}, \mathrm{Cu}$ and $\mathrm{Au}$, many features of them fit to the iron oxidecopper-gold style of mineralisation described in the literature (e.g., Hitzman et al., 1992; Barton and Johnson, 2000; Hitzman, 2000; Goad et al., 2001; Mark \& Williams, 2001). These are: 1) regional scapolitisation and albitisation with overprinting, structurally controlled, intense albitisation, 2) local, also structurally controlled, enrichment of $\mathrm{Fe}, \mathrm{S}, \mathrm{P}$, and $\mathrm{V}$, and 3) highly saline fluids associated with scapolisation, albitisation and formation of the skarnoids and magnetite deposits.

Characteristic for many iron oxide-coppergold-type deposits is that sulphides and gold of younger metasomatic stage overprint magnetiterich and/or highly albitised rocks. The late fluid can be of low-salinity, $\mathrm{CO}_{2}$-rich, and derived from felsic magmatism (Pollard, 2000; 2001). Although the Raajärvi and Puro iron deposits 
show signs of a later-stage metasomatism (carbonatisation and oxidation of magnetite), it has apparently only remobilised the pre-existing sulphides.

Our suggestion for the model of ore genesis in the Misi region is as follows: $\mathrm{Na}-\mathrm{Cl}$-rich fluids, capability of which to transport heavy metals as chloro-complexes have been demonstrated in numerous works (e.g., Eugster \& Chou, 1979; Whitney et al., 1985; Hemley et al., 1992; Hemley \& Hunt, 1992; Williams, 1994), albitised the country rocks and mobilised $\mathrm{Ca}, \mathrm{Mg}, \mathrm{Fe}, \mathrm{K}$ and precipitated and enriched them in structurally (fault or shear zones) and/or lithologically (dolomitic marble) favourable locations from the circulating metalrich fluids. The source of the iron could have been the igneous mafic to intermediate country rocks or sedimentary iron formations associated to dolomitic marble. The metal deposition could have resulted due to dilution, by introducing $\mathrm{CO}_{2}$ from the marbles, or by a change in $\mathrm{T}, \mathrm{P}, \mathrm{pH}$ or Eh.

According to deformation history of the skarnoids, albitites and iron ores, the intense albitisation, skarnification and formation of magnetite masses probably occurred during pre- or syn- $\mathrm{D}_{1}$ faulting, after the intrusion of LREE-enriched gabbros. This suggests that the age of the skarnoids and the ore formation is ca. 2120 $1900 \mathrm{Ma}$

\section{Summary}

The Palaeoproterozoic Misi region comprises a volcano-sedimentary sequence intruded by two types of gabbros and by late-orogenic granitoids, and was subjected to intense and multistage alteration. Three major stages of deformation can be recognised in the region: 1) $\mathrm{D}_{1}$ related to N-S compression, 2) $\mathrm{D}_{2}$ related to NESW compression with ductile deformation, and 3) $D_{3}$ due to $E-W$ compression with brittle-ductile and brittle deformation. Peak regional metamorphic conditions varied across the belt from upper-greenschist to upper-amphibolite facies.
Supracrustal rocks of the Misi region consist of dolomitic marble, quartzite, arkosite, mica shist, graphite-bearing schist, mafic tuff and tuffite, and mafic lava. Geochemically, the mafic lavas form two distinct groups: a LREE-depleted and a slightly LREE-enriched types. Based on geochemistry and volcanic structures, we correlate the LREE depleted amygdaloidal lavas to the $2.09 \pm 70 \mathrm{Ma}$ Jouttiaapa Formation lavas in the western part of the Peräpohja Schist Belt. Based on carbon isotope data, we correlate the quartzites and dolomites of the Misi region to the Kivalo Group quartzites and dolomites in the western part of the Peräpohja Schist Belt. We consider the mafic tuffites, graphite bearing schists and arkosites as the youngest supracrustal units of the Misi region. The LREE-enriched, $2117 \pm 4$ Ma gabbros and flat REE-signature gabbros of unknown age comprise the major intrusive rocks in the region. Late-orogenic granitoids are abundant especially in the northern margin of the region.

Multistage and -type alteration is characteristic for the area. Regional weak to moderate albitisation and scapolisation is locally overprinted by intense albitisation and accompanied with skarnification of sedimentary sequence containing dolomitic marble, quartzite, and minor volcanic rocks and mica schist. Local serisitisation and silicification has taken place along a major NW-trending shear zone. Carbonate veining and carbonatisation of the skarnoids and iron ores took place, at least, at Raajärvi and Puro iron deposits.

Based on deformation structures, the intense albitisation and skarnification is related to preor syn-D faulting or shearing. Structurally controlled serisitisation and silicification is related to $\mathrm{D}_{2}$ dextral shearing. Brittle nature of carbonatisation and carbonate veining suggest a relationship with $\mathrm{D}_{3}$ deformation.

The iron deposits are hosted by skarnoids within ca. 2220-2120 Ma quartzite-dolomitic marble unit and albitites formed by albitisation of $2117 \pm 4$ Ma gabbroic rocks highly evolved by magmatic differentiation and assimilation. The 
deposits show weak enrichment of $\mathrm{P}$ and $\mathrm{V}$ and weak local enrichment of $\mathrm{S}, \mathrm{Cu}, \mathrm{Co}, \mathrm{Au}$ and $\mathrm{Te}$ compared to their wall rocks. The deposits were formed between ca. 2120 and 1900 Ma. Iron was mobilised from mafic to intermediate country rocks or from pre-existing syngenetic iron formation by saline fluids which circulated during pre- or syn- $\mathrm{D}_{1}$ faulting or shearing.

\section{Acknowledgements}

Authors wish to express their gratitude to the following persons: Juhani Ojala for his assistance on structural geology work of the Misi region, Satu Mertanen

\section{References}

Appleby, A.-K. \& Willams, P.J., 1988. Epigenetic tourmalinite and arsenopyrite in the aureole of the Leinster batholith, SE Ireland. Mineralium Deposita 23, 247-255.

Barton, M.D., Ilchik, R. P. \& Marikos, M. A., 1991. Metasomatism. In: Derrick, D.M.(ed.) 1991: Contact Metamorphism. Mineralogical Society of America, Reviews in Mineralogy 26, 321-350.

Barton, M.D. \& Johnson, D.A., 2000. Alternative brine sources for Fe-oxide(-Cu-Au) systems: implications for hydrothermal alteration and metals. In: Porter, T.M. (ed.) Hydrothermal Iron Oxide Copper-Gold \& Related Deposits: A Global Perspective. Australian Mineral Foundation, Adelaide, 43-60.

Bornhorst, T.J. \& Rasilainen K., 1993. Mass transfer during hydrothermal alterations associated with Au mineralization within the late Archaean Hattu schist belt, Ilomantsi, eastern Finland. In: Nurmi P., SorjonenWard P. (eds) Geological Development, Gold Mineralization and Exploration Methods in the Late Archaean Hattu Schist Belt, Ilomantsi, Eastern Finland. Geological Survey of Finland, Special Paper 17, 273-289.

Ellis, D.E., 1978. Stability and phase equilibria of chloride and carbonate-bearing scapolites at $750^{\circ} \mathrm{C}$ and 4000 bar. Geochimica et Cosmochimica Acta 42, $1271-1281$.

Eugster, H.P. \& Chou, I-M., 1979. A Model for the deposition of Cornwall-type magnetite deposits. Economic Geology 74, 763-774.

Frietsch, R., 1980. The ore deposits of Sweden. Geological Survey of Finland, Bulletin 306, 20 p.

Frietsch, R., 1982. A Model for the formation of the nonapatitic iron ores, manganese ores and sulphide ores of Central Sweden. Sveriges geologiska undersökning, Ser. C, No. 795, 43 p.

Frietsch, R., 1985. Formation of Mg-bearing magnetite and serpentine in skarn iron ores in northern Sweden. Geologiska Föreningens I Stocholm Förhandlingar 106, 219-230. for the anisotropy for magnetic susceptibility determinations, Meri-Liisa Airo for the excellent geophysical maps of the study area, Raimo Lahtinen for the constructive criticism on geochemical interpretation, Erkki Vanhanen and Jorma Isomaa for all their efforts on logistics during the field work. We are also grateful for Martti Lehtinen for the XRD work, and Bo Johanson and Lassi Pakkanen for the SEM-EDS work. We would also like to thank Antti Pakonen and Pirjo Turunen on their assistance during the fieldwork. The constructive critisism by Rudyard Frietsch, Torbjörn Skiöld and an anonymous reviewer led to considerable improvement of the manuscript for which authors are grateful. Outokumpu Oyj Foundation provided financial support for the senior author during this study.

\section{Editorial handling: Torbjörn Skiöld}

Frietsch, R., 1995. Sulphur isotopes in Lower Proterozoic iron and sulphide ores in northern Sweden. Mineralium Deposita 30, 275-284.

Goad, R.E., Mumin, A.H., Duke, N.A., Neale, K.L., Mulligan, D.L. \& Camier, W.J., 2000. The NICO and Sue-Dianne Proterozoic, iron oxide-hosted, polymetallic deposits, Northwest Territories: application of the Olympic Dam model in exploration. Exploration and Mining Geology 9, 123-140.

Hanski, E., Perttunen, V. \& Sorjonen-Ward, P., 1997. Overview of the geology of northern Finland. Geological Survey of Finland, Guide 43, 7-9.

Hanski, E., Huhma, H. \& Vaasjoki, M., 2001. Geochronology of northern Finland: A summary and discussion. In: Vaasjoki, M. (ed.) Radiometric Age Determinations from Finnish Lapland and Their Bearing on the Timing of Precambrian Volcano-Sedimentary Sequences. Geological Survey of Finland, Special Paper 33, 255-279.

Hemley, J.J. \& Hunt, J.P., 1992. Hydrothermal ore-forming processes in the light of studies in rock-buffered systems: II. Some general geologic applications. Economic Geology 87, 23-43.

Hemley, J.J., Cygan, G.L., Fein, J.B., Robinson, G.R. \& D'Angelo, W.M., 1992. Hydrothermal ore-forming processes in the light of studies in rock-buffered systems: I. iron-copper-zinc-lead sulphide solubility relations. Economic Geology 87, 1-22.

Hitzman, M.W., 2000. Iron oxide-Cu-Au deposits: what, where, when, and why. In: Porter, T.M. (ed.) Hydrothermal Iron Oxide Copper-Gold \& Related Deposits: A Global Perspective. Australian Mineral Foundation, Adelaide, 9-25.

Hitzman, M.W., Oreskes, N. \& Einaudi, M.T., 1992. Geological characters and tectonic setting of Proterozoic iron oxide (Cu-U-Au-REE) deposits. Precambrian Research 58, 241-287.

Huhma, H., Cliff, R.A., Perttunen, V. \& Sakko, M., 1990. Sm-Nd and $\mathrm{Pb}$ isotopic study of mafic rocks 
associated with early Proterozoic continental rifting: the Peräpohja schist belt in northern Finland. Contributions to Mineralogy and Petrology 104, 369-379.

Jensen, L.S., 1976. A new cation plot for classifying subalkalic volcanic rocks. Ontario Division of Mines Miscellaneous Paper 66, 22 p.

Karhu, J.A., 1993. Palaeoproterozoic evolution of the carbon isotope ratios of sedimentary carbonates in the Fennoscandian Shield. Geological Survey of Finland, Bulletin 371, 87 p.

Karhu, J.A. \& Holland, H.D., 1996. Carbon isotopes and the rise of atmospheric oxygen. Geology 24, 867-870.

Lauerma, R., 1982. On the ages of some granitoid and schist complexes in northern Finland. Bulletin of the Geological Society of Finland 54, 85-100.

Lesher, C.M., Gibson, H.L. \& Campbell, I.H., 1986. Composition-volume changes during alteration of andesite at Buttercup Hill, Noranda District, Quebec. Geochimica et Cosmochimica Acta 50, 2693-2705.

Lindholm, O., 1976. Raajärven kaivos, Loppuraportti. Unpubl. Report of Rautaruukki Oy. 10 p.

MacLean, W.H. \& Kranidiotis, P., 1987. Immobile elements as monitors of mass transfer in hydrothermal alteration: Phelps Dodge massive sulphide deposit, Mattagami, Quebec. Economic Geology 82, 951-962.

Mark, G. \& Williams, P.J., 2001. Geochemistry of the hydrothermal alteration systems associated with $\mathrm{Fe}$ oxide-copper-gold deposits. Short course, $20^{\text {th }}$ May 2001. Economic Geology Research Unit, James Cook University, $127 \mathrm{p}$.

Marmo, V., 1952. The iron ores of Finland. XIX Congrés Géologique International, Algér. Symposium sur les gisements de fer du monde, $117 \mathrm{p}$.

Marmo, V., 1953. Selostus Kärväsvaaran rautamalmin malmimikroskooppisesta tutkimuksesta. Unpublished raport of Rautaruukki Oy report file 356. M/ 17/Kej-53/1, 3 p.

Melezhik, V.A., Fallick, A.E., Medvedev, P.V. \& Makarikhin, V.V., 1999. Extreme ${ }^{13} \mathrm{C}$ enrichment in ca. 2.0 Ga magnesite-stromatolite-dolomite-"red beds" association in a global context; a case for the world-wide signal enhanced by a local environment. Earth-Science Reviews 48, 71-120.

Mutanen, T., 1997. Geology and ore petrology of the Akanvaara and Koitelainen mafic layered intrusions and the Keivitsa-Satovaara layered complex, northern Finland. Geological Survey of Finland, Bulletin 395, $233 \mathrm{p}$.

Niiranen, T. \& Poutiainen, M., 2003. Iron Oxide-Copper-Gold -style deposits in northern Finland Is there any? An fluid inclusion approach. In: Dégi, J. \& Szábo, C. (eds.) Proceedings of the XVII European Current Research On Fluid Inclusions. Acta Mineralogica-Petrographica, abstract series 2, 142-143.

Nuutilainen, J., 1968. On the geology of the Misi Iron Ore Province, Northern Finland. Annales Academiae Scientiarum Fennicae, Series A. III. Geologica-Geographica, $98 \mathrm{p}$.

Olson, E.O., 1937. Kärväsvaaran rautamalmiesiintymän tutkiminen. Unpubl. report of Suomen Malmi Oy. 53 p.

Orville, P.M., 1975. Stability of scapolite in the system $\mathrm{An}-\mathrm{NaCl}-\mathrm{CaCO}_{3}$ at $4 \mathrm{kbar}$ and $750^{\circ} \mathrm{C}$. Geochimica et Cosmochimica Acta, 39, 1091-1105.
Perttunen, V., 1980. Stratigraphy of the Peräpohja schist area. In: Silvennoinen, A. (ed.) Jatulian geology in the eastern part of the Baltic shield. Proceedings of a Finnish-Soviet symposium held in Finland $21^{\text {st }}-26^{\text {th }}$ August 1979, 139-144.

Perttunen, V., 1985. On the Proterozoic stratigraphy and exogenic processes and related metallogeny. Proceedings of the symposium held in Oulu, Finland August 15-16, 1983. Geological Survey of Finland, Bulletin $331,131-141$.

Perttunen, V., Hanski, E. \& Väänänen, J., 1995. Stratigraphical map of the Peräpohja Schist Belt, northern Finland. In: Kohonen, T. \& Lindberg, B. (eds.) The $22^{\text {nd }}$ Nordic Geological Winter Meeting, abstracts, Turun yliopisto and Åbo Akademi, 152.

Perttunen, V. \& Vaasjoki, M., 2001. U-Pb geochronology of the Peräpohja schist belt, northwestern Finland. In: Vaasjoki, M. (ed.) Radiometric Age Determinations from Finnish Lapland and Their Bearing on the Timing of Precambrian Volcano-Sedimentary Sequences. Geological Survey of Finland, Special Paper 33, 45-84.

Pollard, P.J., 2000. Evidence of a Magmatic Fluid and Metal Source for Fe-Oxide $\mathrm{Cu}-\mathrm{Au}$ Mineralisation. In: Porter, T.M. (ed.) Hydrothermal Iron Oxide CopperGold \& Related Deposits: A Global Perspective, Australian Mineral Foundation, Adelaide, 27-41.

Pollard, P.J., 2001. Sodic(-calcic) alteration in Fe-oxide$\mathrm{Cu}-\mathrm{Au}$ districts: an origin via unmixing of magmatic $\mathrm{H}_{2} \mathrm{O}-\mathrm{CO}_{2}-\mathrm{NaCl} \pm \mathrm{CaCl}_{2}-\mathrm{KCl}$ fluids. Mineralium Deposita 36, 93-100.

Runolinna, U., 1959. Kärväsvaaran kaivos. English summary: The Kärväsvaara mine. Vuoriteollisuus 17, $19-22$.

Saastamoinen, J., 1965. Havaintoja Kolarin ja Misin alueiden rautamalmeista. Unpublished M.Sc. thesis, University of Helsinki, Finland, 117 p.

Sakko, M., 1971. Varhaiskarjalaisten metadiabaasien radiometrisiä zirkoni-ikiä. English summary: Radiometric zircon ages on the Early-Karelian metadiabases. Geologi 23, 117-119.

Siirama, E., 1976. Kaivostoiminta Misin rautamalmialueella vuosina 1958-1975. Vuoriteollisuus 34, 114-118.

Sorjonen-Ward, P., 1995. The Svecofennian orogeny and its relation to deformation in Lapland. In: Kohonen, T. \& Lindberg, B. (eds.) The $22^{\text {nd }}$ Nordic Geological Winter Meeting, abstracts, Turun yliopisto and Åbo Akademi, 201.

Sturchio, N.C., Muelenbachs, K. \& Seitz, M.G., 1986. Element redistribution during hydrothermal alteration of rhyolite in an active geothermal system: Yellowstone drill cores Y-7 and Y-8. Geochimica et Cosmochimica Acta 50, 1619-1631.

Sun, S.-s. \& McDonough, W.F., 1989. Chemical and isotopic systematics of oceanic basalts: implications for mantle composition and processes. In: Magmatism in the ocean basins. Geological Society, Special Publication 42, 313-345.

Wagner, L.R. \& Brown, G.M., 1968. Layered igneous rocks. Olivier \& Boyd, Edinburg and London, $588 \mathrm{p}$.

Vanko, D.A. \& Bishop, F.C., 1980. Occurrence and origin of marialitic scapolite in Humbolt Lopolith, N.W. Nevada. Contributions to Mineralogy and Petrology 81, 277-289. 
Westerlund, P., 1965. Otanmäki Oy, Raajärven kaivos. Yleiskatsaus. Vuoriteollisuus 22, 27-35.

Westerlund, P., Nuutilainen, J. \& Siirama, E., 1968. Otanmäki Oy, Kärväsvaaran kaivos. 1959-1967. Vuoriteollisuus 26, 20-27.

Whitney, J.A., Hemley, J.J. \& Frederick, O.S., 1985. The Concentration of iron in chloride solutions equilibrated with synthetic granitic compositions: the sulphurfree system. Economic Geology 80, 440-460.
Williams, P. J., 1994. Iron mobility during synmetamorphic alteration in the Selwyn Range area, NW Queensland: implications for the origin of ironstone-hosted $\mathrm{Au}-\mathrm{Cu}$ deposits. Mineralium Deposita $29,250-260$.

Winchester, J.A. \& Floyd, P.A., 1977. Geochemical discrimination of different magma series and their differentiation products using immobile elements. Chemical Geology 20, 325-343. 